\title{
Are There Gains to Joining a Union? Evidence from Mexico
}

\author{
Héctor Gutiérrez Rufrancos (D)
}

\begin{abstract}
Union density in Mexico has been in decline since the 1980s. This article provides evidence on the worker compensation gains (losses) made by males upon joining (leaving) a union. These are estimated using a nationally representative labour market survey covering 2005q1-2016q1. The transitions between nonunion and union status are investigated using a difference-in-difference estimator. The findings suggest that joining a union is associated with modest wage gains, contrary to what the literature has shown for most industrialized nations. However, in contrast to this, some union leavers are found to experience a decrease in wages. This article also contributes to the wider literature by providing the first estimates of the longitudinal gain (loss) associated with joining (leaving) a union with respect to non-wage benefits. The findings show joining (leaving) a union increases (decreases) the probability of being in receipt of legally guaranteed benefits such as bonuses and paid holidays. This suggests that although union density may be in decline, unions still have an important role to play in voicing worker's preferences with respect to compensation and ensuring that employers comply with the law.
\end{abstract}

\section{Introduction}

Unions in Mexico have been in decline since the 1980s. Union density has declined from a peak of approximately 14 per cent in 1984 of the male formal labour force to its current rate of approximately 7.5 per cent. While density fell in the 1990s, the early to mid-2000s witnessed a minor resurgence in unionization rates. Yet, most information on the effects of unions relate exclusively to that period. Even then, very little is known about the role of unions in the face of macroeconomic adversity, and their role in bargaining over non-pay packages. This article aims to investigate the union role along 
these dimensions for the recent 11-year period (2005-2016). Recent findings by Gutierrez Rufrancos (2017) suggest that there is a sizeable raw mean wage differential between union members and nonmembers (18-22 per cent). This gap reduces to $6.7-13.8$ per cent once worker characteristics are taken into account. However, there is no recent evidence on the effects of unions with respect to non-wage benefits. Fairris (2006) investigates this issue for the 1990s and finds that unions tilt the whole of worker compensation towards non-wage benefits.

Given the existence of a wage gap attributable to unions, it is salient to ask 'Is there any benefit/loss associated with transitioning in or out of a union?' This article will address the research question by carefully disentangling the wage and non-wage benefits to joining (leaving) a union. The main contribution of this article is in the spirit of the suggestions of Doucouliagos et al. (2018), this article provides the first estimates of the shortrun longitudinal effects of unions on worker non-wage benefits to the literature for a developing country. A large sample of workers is investigated using the Mexican Occupation and Employment Survey, a richly detailed labour force survey conducted on a quarterly basis. This dataset comprises a rotating panel with individuals interviewed for five consecutive quarters. I exploit the panel dimension of these data to identify the union wage differential as well as probability models of non-wage benefits by exploiting worker transitions in joining and leaving unions by using a differences-in-differences identification strategy.

The results reveal that in the short run, the average union joiner perceives a 3.7 per cent increase in wages. When the data are disaggregated, it becomes clear temporary contract workers who unionize - among some of the most vulnerable workers - obtain a wage increase of 21.4 per cent relative to other temporary non-unionized workers. No other wage effects are detected for any other sub-group. Nevertheless, the probability of being in receipt of legally mandated non-wage benefits rises as a consequence of unionizing. This is also found to be consistent across individuals either transitioning firms or contract types.

The results for union leavers suggest that in the short run, they do not perceive decreases in their wages, in particular once differences in characteristics are taken into account. Temporary contract workers who leave unions are the sub-group that find their wages decrease by 32.4 per cent. Equally, union leavers are found to have lower probabilities of holding legally mandated non-wage benefits.

The evidence provided is consistent with the voice concept originally proposed by Freeman and Medoff (1984) suggesting that these effects remain relevant today in Mexico. Unions through collective worker ensure that firms provide all of the legally mandated benefits to which a worker is entitled, without taking reprisals on workers themselves. Leavers forfeit these benefits, perhaps in exchange for maintaining wages commensurate with their erstwhile union bargained wage levels. Further, I consider the 'facilitation' effect of unions proposed by Budd (2004, 2007) and conclude that while this may 
explain increases in awareness of non-wage benefits for joiners, the loss in mandatory benefits suggests that facilitation is not consistent with my findings for the Mexican context.

The article is laid out as follows: I draw upon the developed country union literature and provide a brief background to the legal requirements of the Federal Labour Law in Section 2. The data are described in more detail in Section 3. The methodology is detailed in Section 4. Section 5 presents the empirical results, some robustness checks are presented in Section 6, and finally Section 7 concludes.

\section{Background}

\section{Federal Labour Law Provisions in Non-Wage Benefits}

My aim in this article is to investigate the effect of joining and leaving a union. This effect will be investigated focusing on both the wages and the non-wage components of remuneration. In the Mexican context, these are set out by Article 123 of the Constitution and detailed by the Federal Labour Law (FLL), which define the working conditions that a worker may expect in employment. The Constitution creates a legal separation in the rights of workers by their employment sector, as it has two separate subsections ' $A$ ' covering private sector workers, and 'B' dealing with public sector workers. The FLL only applies to private sector workers. The labour rights of public sector workers are subject to the Federal Law of State Workers. This duality in law implies that there are actually very distinct legal regimes that cover the benefits and entitlements of public sector workers, as such this investigation will focus solely on private sector workers.

The FLL outlines a number of mandatory non-wage benefits that must be provided directly by an employer. These include, but are not limited to Aguinaldo, or Bonus. This is a mandatory annual payment that must be equivalent to a minimum of 15 working days salary (Clause V Art. 89 FLL). If the worker did not complete a full year at the firm, he or she is entitled to the pro rata equivalent. If a worker leaves his or her employment, regardless of voluntarily or involuntarily, prior to the bonus being paid out he or she is entitled as part of his or her severance payments to take the proportion of the bonus earned.

Chapter IV of the FLL entitles workers to six days of paid holiday once they have been employed for a year, and each additional year at the firm secures another day of paid leave. Once 12 days has been reached an additional two days are accrued every five years with the firm. It should be noted that this does not include national holidays, which are considered paid leave days, regardless of one's seniority at the firm.

The FLL and the Law of Social Security stipulate that all workers in an worker-employer relationship must be registered with the Mexican Institute of Social Security (IMSS). Registration to Social Security allows workers to obtain certain benefits such as health care and pensions. 
The FLL outlines the legal framework under which unions operate. Union membership is defined as voluntary, and the law states that one may join or leave a union without being the subject of coercion. Joining a union may take multiple forms. In principle, however, workers must form a new union, which may then be associated with a larger national unions congress. When changing jobs one may be able to enter a union to obtain a union contract. Any worker over 14 years of age may join a union. All unions need to be registered to the relevant Arbitration and Conciliation Commission.

A new 'union' cannot begin operations such as negotiating a collective contract with an employer or engage in other activities such as strikes until it is officially registered by an Arbitration and Conciliation Commission. The FLL also regulates the internal workings of unions, it requires that unions have statues and freely elect their officers but the law falls short of explicitly calling for secret ballots. Instead, elections of union members are stipulated by law to occur during plenary sessions. This lack of anonymity coupled with exclusion clauses have led to a democratic deficit within unions associated with larger confederations. This lack of internal democracy allows for union leadership to become unaccountable to the rank-and-file members (Middlebrook 1995; Fairris 2006; Bensusán and Middlebrook 2012).

Enshrined in the FLL is the freedom to both unionize and leave a union (Art. 359 FLL). The law does not proscribe the procedure for voluntarily leaving a union, and only lays out the rules for someone to be involuntarily expelled from a union, for which a two-thirds majority based on a nonsecret vote is required. The details of leaving a union are left to each union's constitution. However, in general, leaving a union is an administratively expensive affair. One may resign their union membership by writing a letter formally doing so, and having it notarized. This will then need to be presented for ratification to the relevant Arbitration and Conciliation Commission. Finally, this is presented to the union leadership. However, this may also have implications for a worker's contract. If the collective contract is for unionized individuals, workers may need to reapply for their jobs to obtain a role as a trabajador de confianza, that is a non-unionized role within the same firm. Although exits from the union sector through the formal institutional approach are rare, this is nevertheless a feature of the Mexican labour market.

\section{Literature Review}

The traditional neoclassical labour economics view on unions characterizes them as monopolists. The absence of unions would see competition between individuals for jobs, which would lead to firms offering market clearing pay packages that reward the workers for their marginal contribution to the production process. The composition of the pay packet should be attractive to the marginal worker in order to ensure labour market competitiveness. Thus, if workers were interested in better non-wage benefits (e.g. pensions, profit-sharing, medical cover), they would settle for a job with a lower wage 
that provides better benefits. In this view, unions distort the pay composition of the remuneration package and increase it above the competitive level through the threat of increasing firm costs(through strike action, for example).

Freeman and Medoff (1984) offer an complementary view of unions. In a series of seminal studies, they investigate what they describe as the 'other face' of unionism. This view, developed from earlier work by Hirschman (1971) and Slichter et al. (1960), is coined by Freeman and Medoff as 'collective voice'. For example, individuals who face economic problems may use two methods to solve these problems. The first is exit-and-entry. In this instance, it would imply that the one way in which an individual may make his or her discontent felt is through quitting his or her job. The second alternative is what Hirschman called 'voice'. It emphasizes the use of communication to lead to better outcomes. A direct implication of this as suggested by Harcourt et al. (2004) is that Union 'voice' may be a direct mechanism through which workers ensure that employers comply with labour law. Individual workers may be aware that their legally mandated rights are not being met, and may not speak up as they may fear employer retribution may leave them out of a job. However, through the mechanism of union collective voice, workers are able to demand their entitlements from employers without the fear of reprisals. Unions, therefore, serve as a medium for collective voice that may be better able to speak to management to ameliorate work conditions, which may include securing higher standards of living for workers both in the present (paid holidays, bonuses) and in the future (pensions). The improvement of working conditions is the main channel identified by Freeman and Medoff as affecting worker productivity. Voice thus far has been presented as being unambiguously positive, but there may be instances in which individual worker voice may lead to inefficient outcomes. Unions in this case are political institutions, which, if elected democratically, respond to the needs of their median voter (member). This suggests that they will bargain with management over the composition of pay packets to reflect their membership's median preferences over those of the marginal worker, holding compensation fixed, under the assumption of democratic unions. However, it must also be acknowledged that under the monopoly view of unions, one could reallocate compensation towards non-wage benefits, so voice is one of many competing explanations for increased non-wage remuneration in the union sector. Nevertheless, evidence for both compliance with labour law and increases in non-wage benefit holding may only be predicted by adopting the voice approach to unions.

More recently, Budd $(2004,2007)$ has argued for a third face of unionism, that of union facilitation. He suggests that unions not only act as a medium for the collective voice of workers, but they may also play an important role in the diffusion of knowledge about existing benefits to which workers may be entitled. Hirsch et al. (1997) suggest that part of the differential in compensation between union/nonunion workers may be due to the assistance unions provide. This is supported by evidence in Budd and Brey (2003), 
who find for unionized hourly employees that there is a greater probability of having heard of the American Family and Medical Leave Act. Budd and McCall (1997) find that unemployment insurance is more likely to be taken up by union than nonunion members. Thus, the main channel by which facilitation works is purely by increasing information availability to workers, either through shop stewards, newsletters or more general union network effects.

\section{Unions and wages}

There is an extensive literature on union/nonunion wage gaps for developed countries. ${ }^{1}$ Overall there is a consensus among labour economists that the union wage gap for the USA is in the range of 10-20 per cent (Fuchs et al. 1998). Lewis (1986b) surveys the research for the USA from 1968 to 1979, and finds that after adjusting for differences in characteristics, the union wage gap ranges from 9.6 to 16.4 per cent. Jarrell and Stanley (1990) take the studies that Lewis surveyed and perform a meta-analysis for the USA from 1968 to 1979. They find that the union wage gap ranges between 8.9 and 12.4 per cent. Similar magnitudes have been found for other developed countries (Pencavel 1974; Stewart 1983; Robinson and Tomes 1984; Callan and Reilly 1993).

Union status, however, is not randomly determined (Robinson 1989). Numerous studies have attempted to address this issue with selection methods such as those proposed by Lee (1978), Heckman (1979) or Lee (1983) with varying degrees of success (Lewis 1986a). The studies have struggled to ascertain in which direction the bias is likely to be. Booth and Bryan (2004) use British data from an employer-employee linked survey, and detect positive selection into unions, once this is accounted for the union wage premium disappears. Main and Reilly (1992) use British data to estimate the union wage gap for females, controlling for selection into unions and employment status. Once this is taken into account, the wage gap is found to be smaller. The identification of selection effects in this literature is difficult. Unsurprisingly, this has been due to the difficulty in finding instruments that shift the probability of joining a union but not the wage level. Rios-Avila and Hirsch $(2012,2014)$ suggest that selection may not necessarily be an issue at either the mean or the median. However, they suspect that it is likely to be a more important issue at either tail of the wage distribution.

More recent studies for developed countries have focused on trying to find causal estimates of the union wage gap using regression discontinuity design procedures. DiNardo and Lee (2004) focus on the results of contested union elections in enterprises, and they find that there are short-run differences in terms of wages between those that narrowly voted in unions versus those that rejected them, they find near zero wage effects. This approach was then developed further by Frandsen (2014) who matched the election data with confidential household information. He concludes that at the establishment level, data exhibit substantial selection, correcting for this, a narrow election for unionization leads to a decline in overall payroll. This effect is due to worker composition, where older and higher remunerated workers exit, 
while younger lower remunerated workers join and stay. Card et al. (2018) investigate the trends in union effects at the first and second moments of the wage distribution for the USA and Canada. Their sample covers the period from the 1980s to the 2010s. At the mean, they provide evidence that the union effects have been declining since the 1980s, and this is compounded by changes in the sectors that unionized individual work. They find that union mean wage effects are larger in the public sector than the private sector. Coupled with a decline in union density this suggests that unions play an important inequality reducing role in the public sector. This is a sharp contrast where wage differentials have narrowed, thus changes in union density are unlikely to decrease inequality.

Estimates for union wage differentials and the impact on wage dispersion were recently surveyed by Freeman (2010) as part of an overview of labour markets in developing countries. The evidence for Africa predominantly focused on wage effects. The wage premium in South Africa for unions is found to range between 8 and 40 per cent at the mean. Moll (1993) estimate the union wage gap at the mean and find the gap to be 24 per cent for black blue collar workers. Schultz and Mwabu (1998) estimate the union wage gap across the conditional wage distribution in South Africa, and find that the wage gap for Africans is greater at the lower ends of the pay distribution and, not surprisingly, decreases with movement up the wage distribution. Their findings suggest those at the bottom end of the distribution have seen their wages increase by 145 per cent, while those in the top decile experience a more modest 19 per cent advantage. Butcher and Rouse (2001) replicate the Schultz and Mwabu study with different data and apply more controls. They find that the wage premium monotonically decreases along the wage distribution. This suggests the existence of a 'sword-of-justice' effect, wherein unions compress the pay distribution. Their estimates suggest that those at the lower ends of the distribution earn an extra 32 per cent, while those at the top enjoy a more modest premium of just 6.7 per cent. Finally, the mean wage gap is found to be 20 per cent. Thus, on the whole, both studies conclude that the wage distribution is compressed by the presence of unions. Hofmeyr and Lucas (2001) apply a series of selection correction techniques to the analysis of the mean wage gap. They find, that dependent on the type of correction mechanism, the wage gap for urban African males increased over the period 1985-1993 from 8 per cent to 20 per cent. Blunch and Verner (2004) report an estimated wage gap of about 6 per cent for Ghana. Baah (2005) reports that the Ghana wage gap increased ranges between 7.8 and 12.6 percentage points in 1992 and 1999. Both studies conclude that unions in Ghana decrease the dispersion of wages. It is worth noting that all these studies relate to the union wage gap for the formal sector. Coverage of union wage effects in the informal sector is, to the best of my knowledge, non-existent, primarily because unions do not organize in these sectors.

Asian estimates of the union wage gap vary by country. Bhandari (2009) reports evidence for a small sample of Indian workers and his findings suggest a wage gap of 6 per cent for contract workers, while permanent workers secure 
a wage gap of 25 per cent. The wage gap for South Korea is found to be small, Kleiner and Lee (1997) find, using establishment-level data, the wage gap to be 7 per cent. Fields and Yoo (2000) study the evolution of the gap over a period of rapid union growth using individual-level data. They report that despite these increases in density, and hence bargaining ability, the gap simply rose from 3 per cent to 6 per cent. Park (2008) finds an all-worker wage differential of 5 per cent, and when disaggregated by gender finds the gap to be 12 per cent and 2 per cent for women and men, respectively.

Turning to the Latin American literature, Arbache and Carneiro (1999) report a wage premium of 5-7 per cent in the manufacturing sector for Brazil. In contrast, Menezes-Filho et al. (2005) detect a union wage effect of 12 per cent for Brazil, using establishment-level data. The Uruguayan dictatorship of 1973-1984 outlawed collective bargaining. Casoni et al. (2005) provide evidence for Uruguay in the period subsequent to the return of democracy, finding that unions increased wages by up to 7.5 per cent. Landerretche et al. $(2011,2013)$ report evidence for the union wage differential for Chile using panel data for 2002-2009. They correct for endogeneity of union status and find that the corrected union wage gap ranges between 18.6 and 24 per cent. Rios-Avila and Hirsch $(2012,2014)$ study the union wage effect for Bolivia and Chile across the wage distribution and apply the Firpo et al. (2009) decomposition technique, which allows the effects of subsets of variables to be isolated. ${ }^{2}$ They find that the Chilean union wage gap is immutable across the wage distribution at about 20 per cent, while the Bolivian raw union wage gap is found to be between 20 and 35 per cent across the wage distribution. They find in both cases that the wage structure accounts for about half of the gap, and also note that unions reduce wage dispersion. Panagides and Patrinos (1994) report the union wage gap in Mexico. They apply a Oaxaca-Blinder decomposition and determine that the all-worker union/nonunion wage gap for 1989 is 10.4 per cent. Fairris (2003) reports the treatment component of a Oaxaca-Blinder decomposition and finds that the adjusted union mark-up declined from 19 per cent in 1984 to 14 per cent in 1996.

\section{Unions and non-wage benefits}

Freeman (1981) was the first study to explicitly examine the effect of unions on non-wage benefit composition. Using the Expenditures for Employee Compensation (EEC), an establishment level survey for the USA, he finds that the a priori predictions that non-wage benefits are greater for unionized firms is upheld by the data. Workplaces with a union density of 50 per cent have 25-35 per cent higher expenditure on non-mandatory benefits. This raw gap, once adjusted for levels of total compensation is reduced to 15-20 per cent. Freeman and Medoff (1984) utilize various individual-level datasets to further analyse this question, ${ }^{3}$ and find that union members are 24 to 32 percentage points more likely than nonunion workers to have a pension. Freeman (1984) uses longitudinal data for the USA and finds that the both the number of fringe benefits, and the incidence of pension provision increase for those 
joining a union, while decreases for those leaving a union. Freeman attributes the lower estimates on wages and non-wage benefits as due to measurement error in the union variable. He develops a theorem which under certain assumptions shows that the longitudinal estimates will underestimate the 'true' union effect. Montgomery and Shaw (1997) find unions to be associated with a larger incidence of pension benefits. Using longitudinal Canadian data, Swindinsky and Kupferschmidt (1991) report that unionized workers are 20 per cent more likely to have a pension plan. Miller and Mulvey (1992) report for Australia, using a longitudinal survey, that the value of fringe benefits are 13.9 per cent higher for union compared to non-union workers. Kornfeld (1993) finds that joining a union in Australia increases the probability of having a pension. Budd (2004) updates the estimates of unions and fringe benefits for the USA and finds that being in a union increases the probability of having employer-provided health insurance and a pension by 16.4 per cent and 18.8 per cent respectively. Budd (2005) updates the Freeman (1981) EEC estimates and finds that the voluntary benefits are 10.5 per cent higher for union compared to non-union members. Budd and Mumford (2004) estimate the effects of unions on family friendly policies. They find that unions increase the probability of parental leave, subsidized childcare, special leave and jobsharing options.

The literature on non-wage benefits reviewed thus far has focused on developed countries. For developing countries, Standing (1992) looks at the incidence of non-wage benefits using establishment-level data for Malaysia. He finds that benefits differ not only between union/nonunion workers but rather that the entitlement to benefits is greater for those unionized by an industry-level union than at plant level. Baah (2005) finds that Ghanaian trade unions significantly increase access to medical, and non-wage benefits by 41 to 48 percentage points. Fairris (2006) reports evidence for Mexico using establishment level data for 1992 and 1999. He finds that for the period prior to NAFTA, unionized establishments offered benefits 140 per cent higher than non-union establishments, and after liberalization this had decreased to 26 per cent. Fairris (2007) further exploits the establishment data to look at the value of fringe benefits as a proportion of compensation, and finds that unions lower this proportion relative to the nonunion sector. The difference is found to be 0.2 per cent in 1992 . However, after trade liberalization, this had widened to 7.2 per cent. Fairris suggests that a lack of research in the area for developing countries is to a large extent due to the unavailability of detailed surveys.

The extant evidence on non-wage benefits and wages reviewed thus far in the literature is exclusively based on the concept of a differential between the union and non-union sector using cross-sectional data. This article aims to look beyond the concept of the gap between the two sectors and investigate the wage and non-wage benefit gain (loss) associated with transitioning to (from) a union job using longitudinal data. This is a gap which both the developing country literature has not considered to date to my knowledge. 


\section{Data}

The analysis in this article utilizes the Encuesta Nacional de Ocupacion y Empleo (ENOE), a nationally representative labour force survey carried out by the INEGI, the Mexican government statistics agency. The survey follows a complex sample design. It is a two-stage self-weighting sample. The first stage stratifies over geographical areas, while in the second stage, households are randomly selected for inclusion in the survey. Each quarter one-fifth of households in the sample are dropped and a new cohort is introduced. Each cohort is interviewed for five consecutive quarters. Thus, every survey quarter contains five cohorts at different points of their respective interview cycle. Unfortunately, the survey only includes the question on union membership in the expanded questionnaire, which is only administered once every calendar year. For the purposes of this article, I restrict the sample to those individuals for whom there are two extended questionnaire responses one year apart. In all instances, this leaves only two temporal observations per period. During the first five quarters of ENOE's existence, households were interviewed using the expanded questionnaire, subsequent applications of the expanded questionnaire have been restricted to once every four quarters. The present study exploits exclusively the between-year transitions. By taking this approach, it ensures that only one single year over change is exploited in estimation. There are 14 editions of the expanded questionnaire during the period of this study. ${ }^{4}$ It is worthwhile remarking that this is guaranteed by only selecting those individuals who had their first interview and fifth interview, respectively. So although alternate cohorts may be selected with differing time periods, these would overweight the proposed analysis by the earlier time period, as well as exacerbate any potential concerns of misclassification error.

The specific question that individuals were asked was: 'In this job do you belong to a union?' Note that this question is asked separately for main jobs and any other jobs that an individual holds. This article is only concerned with the response relating to an individual's primary job as this is the one for which the union decision is most likely to be relevant. The questions pertaining to mandated non-wage benefits are as follows: 'In this job do you receive (bonus | paid holidays)?' and 'Although you may not use it in this job do you receive a retirement fund (pension)?' The nature of the questions asked limit the scope of the analysis. No further information regarding the value of these benefits is asked in the survey questionnaire. Thus, I solely focus on the extensive margin of of these non-wage benefits rather than their value or magnitude.

The nature of the pensions question must be regarded with care. Mexico since 1997 has a defined contributions pension system. Workers who are registered with the Mexican IMSS are automatically enrolled for a pension, regardless of an individual opting-in. For all workers in the labour market prior to 1997, their pension would have been migrated to the privately managed pension funds available. Contributions towards this pension will 
automatically be deducted from their base salary, employers have to match this by law, and the government also adds a small proportion to this pot. Note that workers may also add additional unmatched contributions towards this fund. Workers may opt to have their mandatory pensions managed by the central government 'concentrated' account, or they may choose among 1 of the 21 private providers to invest their pension. Those opting for the 'concentrated' account see their pensions managed by 1 of the 21 private providers, on a rotating three month basis. Given this automatic enrolment, this question must therefore be interpreted with caution, any changes to this variable may be interpreted in two competing approaches. In the first interpretation, any changes in worker perception of this variable is a consequence of the facilitation effect, that is changes will be due to increasing worker awareness of their legal entitlements. Conversely, one could interpret this question as informing on the receipt of private - that is external to the IMSS scheme - pension provision. A priori the alternate interpretation of any pension provision, including state pension should not make sense. This is because for the present analysis, only workers enrolled in IMSS are considered, and by definition are covered by the state pension scheme, however this can be differentially disentangled by looking at the behaviour of those entering unions and leaving unions. Presumably, if workers' awareness of their legal entitlements is the sole barrier to claiming receiving pension payments, then those workers who leave a union should perceive no difference in terms of pension effects.

As hinted above, the nature of the survey creates a challenge for the construction of a panel dataset. For the first six quarters of the survey's existence, a large proportion of the whole sample may be tracked. The proportion that one is able to track depends on the frequency of transitions one wishes to consider. As in the later years, I am only able to track onefifth of the sample between quarters. For the purposes of this article, I have chosen to look at year-on-year transitions, these are precisely identified by exploiting information on the interview order for an individual, focusing on those individuals for whom first and fourth interviews fall within expanded questionnaire quarters.

The literature suggests that wage determination by unions within the public sector is markedly different from that in the private sector (Ehrenberg and Schwarz 1986). This extant literature, coupled with the separate legal regime which governs public sector workers in the Mexican institutional context, are the reasons why I restrict the analysis to those wage earners in the private sector. Public sector unions are subject to a different set of laws (Federal Law of State Workers) that govern their contracts and their legally mandated benefits and also subject to parallel but distinct social security institutions, the Institute of Social Security for State Workers (ISSSTE). A cross comparison across the two categories would, therefore, conflate the power of unions with the legal differences governing both sectors. This creates a restriction which must be acknowledged. There may be unobserved selection which is ignored wherein individuals sort themselves into the public sector and private sector, 
as well as self-employment. I lack the instruments to identify this selection process. It should be noted that both 'treatment' and 'control' in the analysis will be subject to this caveat, thus the estimates presented here can only be taken as measures of the union gain for the private sector. It bears remarking that recent evidence from the USA and Canada finds that the majority of the union wage differential is in the public sector (Card et al. 2018). The present analysis focuses on private sector workers, who are of legal working age (1665). This means that self-employed individuals, workers in the armed forces, and domestic service workers are excluded from our sample.

The sample size, once these restrictions have been imposed, is reported in Table 1 . The dataset for the whole time period contains 92,316 observations, implying there are 46,158 individuals, of which 9,381 transition in and out of unions over the period 2005-2016.

As outlined earlier the provision of fringe benefits is only mandatory among those workers who are in the private sector and are covered by IMSS registration. It should also be noted that all informal workers are, therefore, by definition excluded from this sample. Throughout the literature, there is very little consensus on an exact definition of informality (see Pradhan and van Soest 1995; Gasparini and Tornaroli 2009; Loayza and Sugawara 2009). The multitude of definitions can be synthesized into two competing views: The 'Productive' view of informality, where the informal sector is characterized by 'workers in low-productivity jobs in marginal small-scale and often family based activities' (ILO 1991). Under this definition, the formal sector is likely to be rationed in the number of people it can employ and as such informality is a by-product of waiting for a covered sector job. The second and much more recent definition is recognized by the ILO (2002) and focuses on the legalistic approach, wherein informality is classified as being in a state by which one's work is 'not recognised or protected under the law and therefore receive little or no legal or social protection and are unable to enforce contracts or have security of property rights... [and] are excluded from or have limited access to public infrastructure and benefits'. This definition accepts more broadly that informality is not a simple concept to classify, and as such a means by which we may observe it is as a residual activity: those who are not able to avail themselves of the labour laws. In this article, I take the second approach This is due to the different wage determination process in that segment of the labour force, and the fact that unionization in this sector is fairly fragmented. By focusing on those workers with IMSS registration, this ensures that workers are compliant with the legalistic definition of formality, and subject to subsection ' $A$ ' of the FLL with regard to provision in fringe benefits.

Following Addison et al. (2013), I define two new groups 'Union Joiners' and 'Union Leavers'. Joiners are individuals who are not union members in time $t=0$ but are so in $t=1$. Therefore, they are found to have transitioned into the union sector, and their natural comparison group are those individuals who have never joined a union. That is, in both $t=0$ and $t=1$ they report no union affiliation. Equally leavers are 
TABLE 1

Individual Characteristics of Joiners and Leavers, 2005q1-2016q1

\begin{tabular}{|c|c|c|c|c|}
\hline & $\begin{array}{l}\text { Never } \\
\text { union }\end{array}$ & $\begin{array}{l}\text { Union } \\
\text { joiners }\end{array}$ & $\begin{array}{c}\text { Always } \\
\text { union }\end{array}$ & $\begin{array}{l}\text { Union } \\
\text { leavers }\end{array}$ \\
\hline \multicolumn{5}{|c|}{ (a) $\ln$ (Hourly Wages) in 2010 prices } \\
\hline Pre- and post-transition & $\begin{array}{c}3.183 \\
(0.002)\end{array}$ & $\begin{array}{c}3.314 \\
(0.008)\end{array}$ & $\begin{array}{c}3.354 \\
(0.007)\end{array}$ & $\begin{array}{r}3.300 \\
(0.008)\end{array}$ \\
\hline Pre-transition & $\begin{array}{c}3.194 \\
(0.004)\end{array}$ & $\begin{array}{l}3.316 \\
(0.015)\end{array}$ & $\begin{array}{c}3.373 \\
(0.012)\end{array}$ & $\begin{array}{r}3.323 \\
(0.013)\end{array}$ \\
\hline Post-transition & $\begin{array}{c}3.176 \\
(0.003)\end{array}$ & $\begin{array}{c}3.312 \\
(0.010)\end{array}$ & $\begin{array}{c}3.344 \\
(0.009)\end{array}$ & $\begin{array}{r}3.286 \\
(0.010)\end{array}$ \\
\hline \multicolumn{5}{|l|}{ (b) Bonus } \\
\hline Pre- and post-transition & $\begin{array}{c}0.560 \\
(0.002)\end{array}$ & $\begin{array}{c}0.886 \\
(0.005)\end{array}$ & $\begin{array}{c}0.957 \\
(0.003)\end{array}$ & $\begin{array}{c}0.868 \\
(0.005)\end{array}$ \\
\hline Pre-transition & $\begin{array}{c}0.557 \\
(0.003)\end{array}$ & $\begin{array}{c}0.826 \\
(0.009)\end{array}$ & $\begin{array}{c}0.946 \\
(0.005)\end{array}$ & $\begin{array}{r}0.912 \\
(0.007)\end{array}$ \\
\hline Post-transition & $\begin{array}{c}0.562 \\
(0.002)\end{array}$ & $\begin{array}{c}0.922 \\
(0.005)\end{array}$ & $\begin{array}{c}0.963 \\
(0.003)\end{array}$ & $\begin{array}{c}0.842 \\
(0.007)\end{array}$ \\
\hline \multicolumn{5}{|l|}{ (c) Paid holidays } \\
\hline Pre- and post-transition & $\begin{array}{c}0.242 \\
(0.002)\end{array}$ & $\begin{array}{c}0.562 \\
(0.007)\end{array}$ & $\begin{array}{c}0.744 \\
(0.006)\end{array}$ & $\begin{array}{r}0.537 \\
(0.007)\end{array}$ \\
\hline Pre-transition & $\begin{array}{c}0.244 \\
(0.003)\end{array}$ & $\begin{array}{c}0.449 \\
(0.012)\end{array}$ & $\begin{array}{c}0.739 \\
(0.010)\end{array}$ & $\begin{array}{r}0.630 \\
(0.011)\end{array}$ \\
\hline Post-transition & $\begin{array}{c}0.241 \\
(0.002)\end{array}$ & $\begin{array}{c}0.629 \\
(0.009)\end{array}$ & $\begin{array}{c}0.747 \\
(0.008)\end{array}$ & $\begin{array}{c}0.481 \\
(0.009)\end{array}$ \\
\hline \multicolumn{5}{|l|}{ (d) Pension } \\
\hline Pre- and post-transition & $\begin{array}{c}0.527 \\
(0.002)\end{array}$ & $\begin{array}{c}0.874 \\
(0.005)\end{array}$ & $\begin{array}{c}0.952 \\
(0.003)\end{array}$ & $\begin{array}{c}0.855 \\
(0.005)\end{array}$ \\
\hline Pre-transition & $\begin{array}{c}0.525 \\
(0.003)\end{array}$ & $\begin{array}{c}0.803 \\
(0.010)\end{array}$ & $\begin{array}{c}0.948 \\
(0.005)\end{array}$ & $\begin{array}{r}0.903 \\
(0.007)\end{array}$ \\
\hline Post-transition & $\begin{array}{c}0.528 \\
(0.002)\end{array}$ & $\begin{array}{c}0.916 \\
(0.005)\end{array}$ & $\begin{array}{c}0.955 \\
(0.004)\end{array}$ & $\begin{array}{r}0.826 \\
(0.007)\end{array}$ \\
\hline \multicolumn{5}{|l|}{ (e) Demographic } \\
\hline Under 25 & 0.24 & 0.22 & 0.11 & 0.17 \\
\hline $25-44$ & 0.55 & 0.60 & 0.63 & 0.63 \\
\hline $\begin{array}{l}45+ \\
\text { Gender }\end{array}$ & 0.22 & 0.19 & 0.26 & 0.20 \\
\hline Male & 0.91 & 0.93 & 0.93 & 0.92 \\
\hline Female & 0.09 & 0.07 & 0.07 & 0.08 \\
\hline Married & 0.53 & 0.60 & 0.73 & 0.63 \\
\hline \multicolumn{5}{|l|}{ (f) Job characteristics } \\
\hline Less than 1 year & 0.10 & 0.06 & 0.02 & 0.06 \\
\hline $1-3$ years & 0.42 & 0.41 & 0.24 & 0.34 \\
\hline 4-6 years & 0.19 & 0.19 & 0.18 & 0.20 \\
\hline $7-15$ years & 0.20 & 0.21 & 0.28 & 0.25 \\
\hline $15-25$ years & 0.07 & 0.10 & 0.19 & 0.11 \\
\hline $26+$ years & 0.03 & 0.03 & 0.09 & 0.03 \\
\hline \multicolumn{5}{|l|}{ Short contract } \\
\hline $\begin{array}{l}\text { temporary contract } \\
\text { No contract }\end{array}$ & $\begin{array}{l}0.08 \\
0.47\end{array}$ & 0.12 & $\begin{array}{l}0.08 \\
0.03\end{array}$ & $\begin{array}{l}0.12 \\
0.12\end{array}$ \\
\hline \multicolumn{5}{|l|}{ Firm size } \\
\hline Micro & 0.41 & 0.08 & 0.02 & 0.10 \\
\hline Small & 0.29 & 0.20 & 0.09 & 0.22 \\
\hline Medium & 0.18 & 0.30 & 0.23 & 0.28 \\
\hline Large & 0.11 & 0.42 & 0.67 & 0.39 \\
\hline
\end{tabular}


TABLE 1

Continued

\begin{tabular}{lcccc}
\hline & $\begin{array}{c}\text { Never } \\
\text { union }\end{array}$ & $\begin{array}{c}\text { Union } \\
\text { joiners }\end{array}$ & $\begin{array}{c}\text { Always } \\
\text { union }\end{array}$ & $\begin{array}{c}\text { Union } \\
\text { leavers }\end{array}$ \\
\hline Sector & & & & \\
Agriculture, forestry, fishing and hunting & 0.14 & 0.02 & 0.00 & 0.02 \\
Extractive industry \& utilities & 0.01 & 0.02 & 0.04 & 0.02 \\
Manufacturing & 0.22 & 0.49 & 0.65 & 0.48 \\
Construction & 0.07 & 0.04 & 0.01 & 0.04 \\
Trade & 0.22 & 0.14 & 0.06 & 0.15 \\
Accommodation \& food services & 0.06 & 0.08 & 0.08 & 0.07 \\
Transportation and warehousing & 0.07 & 0.09 & 0.11 & 0.10 \\
Professional, financial \& corporate services & 0.08 & 0.06 & 0.02 & 0.06 \\
Social services & 0.02 & 0.02 & 0.01 & 0.02 \\
Other services & 0.10 & 0.04 & 0.02 & 0.04 \\
Public administration & 0.00 & 0.00 & 0.00 & 0.00 \\
Region & & & & \\
NE & 0.11 & 0.21 & 0.29 & 0.22 \\
NW & 0.23 & 0.16 & 0.11 & 0.17 \\
West & 0.13 & 0.10 & 0.09 & 0.11 \\
East & 0.10 & 0.12 & 0.13 & 0.12 \\
CN & 0.15 & 0.18 & 0.16 & 0.17 \\
CS & 0.07 & 0.09 & 0.08 & 0.09 \\
SE & 0.13 & 0.10 & 0.10 & 0.09 \\
SW & 0.07 & 0.04 & 0.04 & 0.04 \\
$\Delta$ FIRM & & & & \\
Stayers & 0.30 & 0.35 & 0.39 & 0.34 \\
Changers & 0.46 & 0.40 & 0.35 & 0.44 \\
$N$ & 77,894 & 4,625 & 5,041 & 4,756 \\
\hline Note: All & & &
\end{tabular}

Note: All variables are measured at individual level. These data are derived from the extended questionnaires of the ENOE survey. Standard errors for the means of the outcome variables are provided in parentheses. For proportions, these standard errors are derived using the binomial formula.

those individuals who in $t=0$ are union members and in $t=1$ report to no longer have a union affiliation. Their comparison group are those individuals who in both $t=[0,1]$ report to be in a union. This method for identifying union status changers does not distinguish between 'intentional' and 'unintentional' unionization. Intentional unionization is when an individual seeks out a union, and may occur at the same time as one changes job. While 'unintentional' unionization can take many forms, perhaps a union arrives at a work place and seeks to organize it, or through job transitions, where one's new job happens to be unionized, without prior intent. These distinctions requires foreknowledge of an individual's intent. This information is not included in ENOE. The closest that one can disentangle this is to look at other changes that occur simultaneously with a union transition. For illustrative purposes, those transitions will be identified by looking at changes in an individual's self-reported tenure in a firm. Those individuals who report having an employer tenure lower than one year and who were employed in the previous period are assumed to have changed job. 
Wages are defined as the log of the gross hourly wage, which is an individual's gross wage divided by the hours worked. This is deflated using the National CPI for Mexico provided by INEGI. Thus wages are expressed in December 2010 prices. The coverage of non-wage benefits in the ENOE survey is limited. The respondent is asked whether they are in receipt of the following: bonuses or paid holidays. The information regarding pensions is reported as the availability of a pension regardless of whether or not an individual is a recipient.

Table 1 reports the summary statistics for the whole sample of joining/leaving transitions. It is notable that unlike the average wage gap, the average wage difference between joiners and never union individuals is about 12.2 per cent prior to joining a union, this gap is increased to 13.6 per cent after joining a union. This gives a simple difference-in-difference estimate of joining a union of 1.4 per cent, which is not statistically significant. Equally, the gap between leavers and always union individuals is found to be -5 per cent in favour of always union members prior to leaving, and this falls to -5.8 per cent, suggesting a difference-in-differences estimate of -0.8 per cent for the wage loss concept, which is too found to be statistically insignificant. With respect to demographic characteristics the average joiner and leaver do not appear to be dissimilar.

Looking at the distribution of available non-wage benefits between joiners and never union members, there is a notable difference in the incidence of provision of these benefits. The unadjusted difference-in-difference estimates, calculated from Table 1, suggest that union joiners perceive an increase in the incidence of non-wage benefits in the range of 9.1-18.3 percentage points. The $z$ statistics for these are 8.3,11.9 and 9.4 for bonuses, paid holidays and pensions, respectively. All of these are highly significant. For union leavers, the unadjusted difference-in-differences the decline in incidence of non-wage benefits is between 8.7 and 15.7 percentage points. Where the relevant $z$ statistics for these are 7.6, 8.2 and 7.1 for bonuses, paid holidays and pensions, respectively. All of these are highly significant. The largest difference is found to be in the incidence of paid holidays. This suggests that there are issues with compliance with FLL in the formal sector. These estimates suggest that there may be both a union facilitation and union voice effect in action. Unfortunately, due to limitations with the data, I am unable to investigate how the magnitude of the reported bonuses vary across joiners/never union and leavers/always union individuals.

Many of the job characteristics reveal the same pattern. On average union 'joiners', 'leavers' and 'always members' are remarkably similar. The rest of the labour force, however, appears to be workers without a contract, predominantly working in micro firms (i.e. those with fewer than ten workers). It should be noted that although a worker may not hold a written contract the FLL explicitly states that once an employer-employee relation has begun one is entitled to all of the non-wage benefits described therein. There seems to much more dispersion across different sectors, unlike for those union members, concentrated in large firms, often in the manufacturing sector. 


\section{Methodology}

As outlined in the previous section, the objective of this article is to investigate the effects of joining/leaving a union on wages, bonuses, holidays and pension provision. Let us assume that the outcome of interest, denoted $Y$, for individual $i$ in transition year $t$ in quarter $q$ is given as follows:

$$
Y_{i t q}=\alpha_{i}+\gamma_{q}+\phi P_{t}+\delta U_{i t q} \times P_{t}+X_{i t q} \beta+\eta_{i t q}
$$

In this particular application, $Y_{i t q}$ is either log wages (in December 2010 prices), or the incidence of non-wage benefits (namely Bonus, Paid Holidays or Pension provision). The vector $X_{i t q}$ contains age and its quadratic, tenure and its quadratic, marital status, firm size dummies, contract type, industry sectoral dummies and state dummies and state quarterly time trends.

The difference-in-differences model presented in expression (1) is a twoperiod model where $\alpha_{i}$ is a time invariant unobserved individual effect, $\gamma_{q}$ is the quarter-year fixed effect, $P_{t}$ is a dummy variable that is equal to 1 where $t=1$. $U_{i t q}$ is a dummy variable which denotes the following two concepts: Firstly joiners, that is individuals who are not union members in time $t=0$ but in $t=1$ are found to have transitioned into a union job, and their natural comparison group are individuals who have never joined a union (that is, in both $t=0$ and $t=1$ they report no union affiliation). Secondly, there are leavers, that is individuals who in $t=0$ are union members and in $t=1$ they report as no longer having union affiliation. Their comparison group are those individuals who in both $t=0,1$ report to be in a union. Thus, the model will be separately estimated for each group. The vector $X_{i t q}$ is a vector of individual and job-specific characteristics. The parameter estimate of interest from equation (1) is the difference-in-differences estimate, which is given by $\widehat{\delta}$. This estimate is the Average Treated on the Treated estimate (ATT) and may be interpreted as the wage (non-wage benefit) gain/loss associated with the union transition. The tables exclusively report the estimates of this parameter. This parameter is estimated by using a two-period fixed effects model. The non-wage benefits difference-in-difference parameter is analogous to (1), and estimated by OLS using a linear probability model. ${ }^{5}$

It bears remarking that the ATT estimate is by its very nature one which encapsulates the experience of the marginal worker either joining or leaving a union relative to their appropriate control group. The successful identification of this effect is conditional on having parallel pre-trends between the treatment and comparator group, but due to the two-period nature of this analysis, it is an untestable proposition. Equally, it is worth bearing in mind that the marginal worker is unlikely to have the same characteristics as that of the average worker, as can be noted from the differences in means in column 3 of 1 . Nevertheless, the ATT by definition cannot give the Average Treatment Effect (ATE), or the full union effect. This is to say that the effects under discussion pertain solely to those who are 'at risk' of joining and leaving, due to their self-selected nature they may not be relevant for those individuals whom never 
unionize, although conceptually related to the population ATE, the ATT does not inform upon the question 'What if an individual with population average characteristics joins a union'. The intention of these estimates is to identify the effect for those who undergo the treatment.

\section{Results}

Table 2 presents the estimates for the gains associated with joining a union. The table presents the estimate for the $\widehat{\delta}$ parameter in expression (1). The estimates are for the pooled transitions over the whole time period $2005 \mathrm{q} 1-$ 2016q1. Individuals are separated into union 'joiners' and union 'leavers' with their respective comparison groups being those individuals who have never been unionized, and those who over the course of the survey always report belonging to a union. Thus, the estimate gives the 'short-run' effect of unionizing when compared to the group of those individuals who never joined a union. The row of baseline estimates reflect the whole available sample, while each successive row represents the estimates for a particular sub-sample.

Throughout the analysis presented here, the data will be analysed by different sub-samples which have been chosen as being more restrictive than the baseline estimate where all the available observations are used, within the restrictions outlined above. The sub-samples under consideration include the disaggregation of contract types (namely permanent, and temporary contracts only), Business size (namely excluding micro businesses, and permanent contract and excluding micro businesses) as well as trying to determine what the effect of 'intentional' unionization versus 'passive' unionization, by estimating for the sub-samples of individuals changing firms and those remaining in firms. For the above listed sub-samples, in all instances the estimates presented here reflect exclusively that subset. So for example, the temporary contract sub-sample only includes joiners or leavers whom in both $t=0$ and $t=1$ held a temporary contract.

Over the whole period, the average wage gain for the average union 'joiner' is found to be weakly statistically significant. I find that on average, those individuals who join a union see their wages increase by 3.7 per cent relative to never unionized individuals. In order to tease out the effect, I re-estimated equation (1) on different sub-samples. It can be seen that the wage effects reported for the overall sample are mainly driven by those individuals who hold a temporary contract. Temporary workers who unionize see their wages increase by 21.4 per cent relative to their never unionized counterparts.

'Never union' individuals are predominantly clustered in micro firms, while union 'joiners' are on average more likely to be found among larger firms. This poses a potential issue in comparing these two sub-samples as it could be argued that small firms have fundamentally different labour relations, and are unlikely to even have a union presence. However, excluding this particular sub-sample yields a broadly similar story as that for the aggregate, namely that there is no short run union wage gain. 
TABLE 2

Difference-in-Differences Estimates of Joining a Union 2005q1-2016q1

\begin{tabular}{|c|c|c|c|c|}
\hline & Wages & Bonus & Paid holidays & Pension \\
\hline \multirow[t]{2}{*}{ Baseline } & $0.037^{* * *}$ & $0.038^{* * *}$ & $0.123^{* * *}$ & $0.056^{* * *}$ \\
\hline & $(0.014)$ & $(0.012)$ & $(0.018)$ & $(0.010)$ \\
\hline$N$ & 82,519 & 82,519 & 82,519 & 82,519 \\
\hline \multirow[t]{2}{*}{ Temporary contract } & $0.194^{* *}$ & $0.172^{* * *}$ & $0.131^{* * *}$ & $0.134^{* *}$ \\
\hline & $(0.087)$ & $(0.057)$ & $(0.050)$ & $(0.064)$ \\
\hline$N$ & 35,189 & 35,189 & 35,189 & 35,189 \\
\hline \multirow[t]{2}{*}{ Permanent contract } & -0.003 & -0.005 & $0.096^{* * *}$ & $0.037^{* * *}$ \\
\hline & $(0.022)$ & $(0.009)$ & $(0.028)$ & $(0.013)$ \\
\hline$N$ & 27,583 & 27,583 & 27,583 & 27,583 \\
\hline \multirow[t]{2}{*}{ Exclude micro businesses } & 0.022 & $0.027^{* * *}$ & $0.117^{* * *}$ & $0.048^{* * *}$ \\
\hline & $(0.017)$ & $(0.010)$ & $(0.021)$ & $(0.011)$ \\
\hline$N$ & 43,337 & 43,337 & 43,337 & 43,337 \\
\hline \multirow[t]{2}{*}{ Permanent exclude micro } & -0.007 & 0.002 & $0.101^{* * *}$ & $0.046^{* * *}$ \\
\hline & $(0.025)$ & $(0.009)$ & $(0.030)$ & $(0.014)$ \\
\hline$N$ & 21,755 & 21,755 & 21,755 & 21,755 \\
\hline \multirow[t]{2}{*}{ Firm stayers } & 0.041 & 0.005 & $0.143^{* * *}$ & $0.036^{* *}$ \\
\hline & $(0.027)$ & $(0.018)$ & $(0.030)$ & $(0.018)$ \\
\hline$N$ & 24,637 & 24,637 & 24,637 & 24,637 \\
\hline \multirow[t]{2}{*}{ Firm changers } & 0.031 & $0.067^{* * *}$ & $0.114^{* * *}$ & $0.089^{* * *}$ \\
\hline & $(0.024)$ & $(0.016)$ & $(0.030)$ & $(0.017)$ \\
\hline$N$ & 37,987 & 37,987 & 37,987 & 37,987 \\
\hline
\end{tabular}

Note: The model specification follows (1) in the text. Each column reports the difference-indifferences $(\widehat{\delta})$ estimate obtained from the pooled time sample. This gives the effects of joining a union independent of the business cycle. The errors for these estimates are clustered at the municipal level. The regressions reported include the demographic and job-specific characteristics outlined in panels (e) and (f) of Table 1. The regressions also include state-specific time trends. For definitions of the dependent variables, see text in Section 3.

$* * *, * *$ and $*$ denote statistical significance at the $1 \%, 5 \%$ and $10 \%$, respectively.

The evidence presented for non-wage benefits is the first of its kind exploring the longitudinal impact of joining/leaving a union. The poor macroeconomic performance of the Mexican economy in the 1980s and 1990s coupled with a decline in union membership altered the discourse of unions. The rhetoric of trade unions shifted towards the concept of the 'social wage' (Middlebrook 1995). This language suggests that unions seek to maximize non-wage benefits for their rank-and-file. This is borne out by the estimates obtained. Union joiners are consistently and significantly more likely to be in receipt of 'mandatory' benefits as guaranteed by the FLL. Looking at the whole sample there is a modest increase in the probability of being in receipt of bonuses of 3.7 percentage points. This suggests a 3.2 per cent increase in the incidence of bonuses if this is evaluated at the pre-transition average. ${ }^{6}$ Looking at the sub-samples confirms a similar pattern. The effect is highest for those in temporary contracts, while there appears to be no gains to unionization for those workers who have permanent contracts. This may be explained, in part, by the legal entitlement that is afforded to permanent workers by the FLL. These guarantees are undefined for part-time workers and those with different contract types. Thus, union gains perhaps change the distribution of 
non-wage benefits for those workers. Dependent on the composition of union membership this could be considered consistent with the union voice effect, if the median union member is one holding a temporary contract. This would also explain the magnitude of increased incidence of these effects with respects to bonuses. Workers on temporary contracts who join a union experience an increase of 17.2 percentage points in the probability of being in receipt of an end-of-year bonus, relative to sub-sample of never union workers. This effect, when evaluated at the relevant pre-transition incidence implies an increase of 15.2 per cent. As with the estimates for wages, excluding micro enterprises decreases the corresponding estimated $\widehat{\delta}$ parameter. Equally, the effect on bonuses can only be detected from individuals who change their firm. Bonuses in the Mexican context are a real and tangible addition to a worker's salary. However, crucially, this fringe-benefit is disbursed only once per annum and traditionally it is equivalent to at least one month's wages. It does not count as a part of the 'salary' concept, thus, enjoying higher pay due to a bonus does not increase other proportional benefits such as employer pension contributions.

A similar pattern is discernible from the other non-wage benefits. Joiners are found to be 12.3 and 5.6 percentage points more likely to be in receipt of paid holidays and have private pension schemes available for workers, respectively. These, when evaluated at their correspondent pre-transition incidences imply increases of 9.2 and 4.8 per cent, respectively. In these sets of non-wage benefits, joiners are consistently found to have a higher probability of being in receipt of these 'mandatory' non-wage benefits, even if one has a permanent contract. These estimates are curious as under the FLL all individuals who work for firms should be registered with the IMSS.

However, the estimates suggest that the probability of being in receipt of these fringe benefits (which should be 100 per cent for all full-time salaried formal workers) is higher for those who join unions. This suggests that unions are acting as a mechanism which ensures that employers provide workers with all of their legal entitlements. Unfortunately, without the ability to further delve into the magnitude of the non-wage benefits provided I am unable to determine to what extent union bargaining is increasing the generosity of these benefits relative to their never union counterparts. Analytically, one could consider the estimates presented here as being indicative of union facilitation effects, that is workers once unionized are made aware of their already existing benefits, so when surveyed about non-wage benefit coverage they change their response. As discussed earlier, this may be a particular concern with regard to pension provision as the survey question is vague regarding the pension concept covered. However, I argue that the findings for joiners are unlikely to be indicative of a pure 'facilitation' effect. This is because of the salience of bonuses and paid holidays. A non-wage benefit without immediate effect may be less salient to workers and thus may have imperfect recollection of what benefits are provided in their contract. However, bonuses and paid holidays have direct implications for workers, and through this increased salience, it is unlikely that non-union individuals would be unaware of their legal entitlement to these benefits. 
TABLE 3

Difference-in-Differences Estimates of Leaving a Union, 2005q1-2016q1

\begin{tabular}{lcccc}
\hline & Wages & Bonus & Paid holidays & Pension \\
\hline Baseline & -0.032 & $-0.051^{* * *}$ & $-0.101^{* * *}$ & $-0.046^{* * *}$ \\
& $(0.019)$ & $(0.012)$ & $(0.024)$ & $(0.013)$ \\
$N$ & 9,797 & 9,797 & 9,797 & 9,797 \\
Temporary contract & $-0.391^{* * *}$ & -0.111 & 0.035 & -0.104 \\
& $(0.125)$ & $(0.123)$ & $(0.102)$ & $(0.115)$ \\
$N$ & 833 & 833 & 833 & 833 \\
Permanent contract & -0.010 & 0.004 & $-0.054^{*}$ & -0.015 \\
& $(0.025)$ & $(0.010)$ & $(0.028)$ & $(0.017)$ \\
$N$ & 6,851 & 6,851 & 6,851 & 6,851 \\
Exclude micro businesses & -0.025 & $-0.042^{* * *}$ & $-0.106^{* * *}$ & $-0.042^{* * *}$ \\
& $(0.021)$ & $(0.011)$ & $(0.025)$ & $(0.012)$ \\
$N$ & 8,985 & 8,985 & 8,985 & 8,985 \\
Permanent exclude micro & -0.014 & 0.001 & $-0.075^{* *}$ & -0.023 \\
& $(0.026)$ & $(0.011)$ & $(0.029)$ & $(0.016)$ \\
$N$ & 6,493 & 6,493 & 6,493 & 6,493 \\
Firm stayers & $-0.058^{*}$ & 0.001 & $-0.075^{*}$ & -0.022 \\
& $(0.035)$ & $(0.018)$ & $(0.044)$ & $(0.020)$ \\
$N$ & 3,582 & 3,582 & 3,582 & 3,582 \\
Firm changers & -0.007 & $-0.076^{* * *}$ & $-0.085^{* *}$ & $-0.047^{* *}$ \\
& $(0.028)$ & $(0.022)$ & $(0.040)$ & $(0.023)$ \\
$N$ & 3,830 & 3,830 & 3,830 & 3,830 \\
\hline
\end{tabular}

Note: The model specification follows (1) in the text. Each column reports the difference-indifferences $(\widehat{\delta})$ estimate obtained from the pooled time sample. This gives the effects of joining a union independent of the business cycle. The errors for these estimates are clustered at the municipal level. The regressions reported include the demographic and job-specific characteristics outlined in panels (e) and (f) of Table 1. The regressions also include state-specific time trends. For definitions of the dependent variables, see text in Section 3.

$* * *, * *$ and $*$ denote statistical significance at the $1 \%, 5 \%$ and $10 \%$, respectively.

The estimated effects of leaving a union are presented in Table 3. The estimates suggest that for the average individual there is wage loss associated with leaving a union. However, my estimates suggest that the average union leaver who remains in their job faces a 5.8 per cent decrease in hourly wages. Indeed, one of the ways in which unions affect wages is through overtime, if the same difference-in-differences exercise is performed on hours worked it is clear that this decrease is unrelated to these, so workers are in fact receiving a lower pay for the same hours. Individuals who have temporary contracts are face a 32.3 per cent decrease in hourly wages. However, due to the reduced sample size, one could argue there is selection on unobservables. For this subsample if one extends the difference-in-differences exercise to hours worked it is clear that this decrease is driven solely by changes in wages. A separate exercise on hours worked shows that there is actually a significant increase of approximately 5.7 hours associated with leaving a union. This suggests that the magnitude would be greater were it not for the compensating increase in hours. The losses of leaving a union are more pervasive with respect to nonwage benefits. 
The FLL entitles individuals with permanent contracts to an end-of-year bonus, paid holidays and a pension. As evidenced in Table 1, there is ample non-compliance in the Mexican labour market. An important contrast from my findings is that while joining a union is associated with increases in the likelihood of being in receipt of these non-wage benefits, so too leaving a union is uniformly associated with decreases in the probability of receiving any non-wage benefits. It is worth noting that firm leaving and union leaving simultaneously should not affect the receipt of bonuses or paid holidays, as the law makes provision for individuals to receive the pro rata equivalent for both of these concepts. Looking at the sub-sample of permanent workers it seems that the entitlements are upheld for the most part. Of the non-wage benefits considered, paid holidays are lost upon exit. Equally, there is a reduction of 5.4 percentage points in receiving paid holidays. Evaluating each of these at the respective incidence of their sub-sample suggests a decline in incidence 3.4 per cent for paid holidays.

From a legal perspective if a worker leaves a permanent contract simultaneously as the event of leaving a union, they would then lose their mandatory entitlement to non-wage benefits. The law suggests that a firm does not have a statutory obligation to provide paid holidays unless an individual has been working at the firm for at least a year. Equally, the bonuses are meant to reflect the period that an individual has been employed with the firm. In cases where they have been with the firm for a period of less than a year, employees are still entitled to pro rata bonus payments. Considering the distinction between voice and facilitation effects of unions the results give a nuanced picture. For those workers for whom mandatory benefits should not change such as those on permanent contracts, we see no change. Thus, it could be argued that the estimates provided reflect to some extent changes in contracting for individuals.

The estimates for the sub-sample of firm 'stayers' and firm 'changers' should, to some extent, assuage these concerns. Firm 'stayers' are those for whom the entitlements to these non-wage benefits should be unaffected by their leaving a union. My findings suggest that this sub-group is, as hypothesized, for the most part unaffected by leaving a union, leading me to conclude that union leavers are being affected due to facing unfavourable contracts in their new firms. However, in terms of facilitation, it is those union individuals who have a heightened awareness of their legal entitlements, so, for these individuals the loss of mandatory benefits should be considered as true changes. In the case of pension provision this is concerning for long run welfare effects.

As a simple exercise to further elaborate this point, I re-estimated the regressions for those individuals who left and changed firm, distinguishing by reason between those who quit and those who lost their job. This sub-sample is defined as those who changed firm, and reported having lost their job - either due to their firm shutting down, or being made redundant. This sample is fewer than 350 individuals, and as such inference should be taken with caution. Quitters may report quitting for numerous reasons, but these individuals are 
not subject to the same losses of non-wage benefits relative to those who quit and always remained in a union. However, the same cannot be said of the sample of individuals who faced involuntary job losses. For this sub-sample of individuals, there are substantial losses to non-wage benefits due to leaving a union. They endure a decline in non-wage benefits of 54.7, 12.9 and 8.1 percentage points for bonuses, paid holidays and pensions, respectively. When these are evaluated at their relative pre-transition means the loss is found to be a decline in bonuses by 60 per cent, 19.5 per cent for paid holidays and 9 per cent for pensions.

\section{Robustness}

There are three concerns with regard to the specification underlying (1), which this sub-section will attempt to address. Firstly, the $\widehat{\delta}$ parameter captures the union member effect upon wages or non-wage benefits under the assumption that, given the controls in vector $X_{i t q}$, a clean estimate of the effect of the average outcome of transitions to or from a union is obtained. However, Table 1 shows that there are marked differences in characteristics, in particular between those individuals who are never union and those joining. This can be mitigated to some extent by adopting a matching approach. Secondly, one may have reservations that the choice of control group may be driving the results presented thus far. In order to address this, the following estimates are presented for swapped control groups. Finally, one may also be concerned that the $\hat{\delta}$ parameter reported may be tainted by the presence of misclassification in the union status of an individual. This would manifest itself through attenuation bias in the coefficients. To allay this issue, I discuss different strategies adopted by the longitudinal literature and report estimates of a series of simulations in which measurement error is randomly introduced.

\section{Conditional Difference-in-Differences}

The parameter of interest estimated has been the ATT. In order to control for differences in observable characteristics between 'joiners' and 'leavers' the conditional difference-in-differences procedure is employed, this is outlined in the Appendix. In practice, the approach that is implemented relies on a twostep procedure.

In the first step, a control function is estimated with a probit model on the relevant sample in order to obtain the propensity score. The model takes the following form:

$$
\operatorname{Pr}\left(U_{i 0 q}=1\right)=\Phi\left(\mathbf{X}_{i 0 q}^{\prime} \beta\right)
$$

where the dependent variable denotes union joiners or leavers and their relevant control groups at time $t=0$. A vector of covariates $\mathbf{X}_{i 0 q}$ at time $t=0$ is then used to control for the initial pre-transition scores, and $\Phi($.$) is the CDF$ 
of the normal distribution. From this model the propensity score for the $i$ th individual is obtained.

These are estimated for the whole sample, and allows me to identify the region of common support. This sample is kept for the next step. The matches are ranked in terms of their respective propensity scores. The Epanechnikov kernel with a bandwidth of 0.06 is used to smooth out the differences between scores. ${ }^{7}$

As it is unlikely that there are exact matches this procedure necessitates the generation of weights. Pairs of observations where the differences in observable characteristics between treated and control groups (namely (Union joiners, never union) and (Union leavers, always union)) are small will be given large weights, while those who are a poor match will be weighted lower.

The second step employs a weighted fixed effects estimator using the weights obtained from the matching estimator. From this, the ATT parameter is given by $\hat{\delta}$ through running the same model as in (1). While a large portion of sub-sample selection has been aimed at mitigating differences between union joiners and never union individuals, the approach considered in this section formally addresses these differences. The identification provided by this procedure is contingent on the observable characteristics between the two groups being a sufficient proxy for unobservables. Thus, matching on these characteristics may help mitigate the role of unobservables. If this assumption is not met, then the procedure will provide estimates for similar observed groups, but unobserved heterogeneity will still prevail.

The results of the conditional difference-in-differences are reported in Tables 4 and 5. These estimates are similar to the results presented thus far in Tables 2 and 3. However, the association previously found for temporary contract joiners is upheld by use of this procedure. This finding is key as it suggests that unions are effective in protecting some of the most vulnerable workers in the economy, those with temporary contracts.

The estimated effects of leaving a union are found to be in line with those obtained from the matched sample of 'leavers' and 'always union' individuals. This exercise is notable for this group, as although there appears to be no real differences in average characteristics between these two groups, the estimates from the procedure reveal that there are wage effects from leaving a union for the average worker. When scrutinizing the subgroups, it becomes clear that this is primarily driven by those workers who leave and happen to be on temporary contracts. It should be also noted that although the estimates provided in Tables 4 and 5 rely on a bandwidth of 0.06 , alternate bandwidths within the range [0.04-0.12] have been used, and these do not materially alter the estimates reported here.

\section{Inverted Control Groups}

A concern that might be expressed about the estimates presented thus far relates to the choice of control group. The act of transitioning union status is not a laboratory experiment. There may be some ambiguity with 
TABLE 4

Conditional Difference-in-Differences Estimates of Joining a Union 2005q1-2016q1

\begin{tabular}{lcccc}
\hline LHS & Wages & Bonus & Paid holidays & Pension \\
\hline Baseline & 0.021 & $0.036^{* * *}$ & $0.106^{* * *}$ & $0.056^{* * *}$ \\
& $(0.019)$ & $(0.011)$ & $(0.020)$ & $(0.011)$ \\
$N$ & 52,239 & 52,239 & 52,239 & 52,239 \\
Temporary contract & $0.146^{*}$ & $0.151^{* *}$ & $0.115^{* *}$ & $0.156^{* * *}$ \\
& $(0.082)$ & $(0.066)$ & $(0.057)$ & $(0.059)$ \\
$N$ & 18,987 & 18,987 & 18,987 & 18,987 \\
Permanent contract & -0.013 & 0.003 & $0.096^{* * *}$ & $0.036^{* * *}$ \\
& $(0.028)$ & $(0.008)$ & $(0.028)$ & $(0.013)$ \\
$N$ & 16,775 & 16,775 & 16,775 & 16,775 \\
Exclude micro businesses & 0.010 & $0.029^{* *}$ & $0.107^{* * *}$ & $0.051^{* * *}$ \\
& $(0.016)$ & $(0.012)$ & $(0.019)$ & $(0.012)$ \\
$N$ & 27,803 & 27,803 & 27,803 & 27,803 \\
Permanent exclude micro & -0.021 & 0.008 & $0.093^{* * *}$ & $0.038^{* * *}$ \\
& $(0.029)$ & $(0.009)$ & $(0.027)$ & $(0.013)$ \\
$N$ & 13,109 & 13,109 & 13,109 & 13,109 \\
Firm stayers & 0.029 & 0.013 & $0.121^{* * *}$ & $0.038^{*}$ \\
& $(0.024)$ & $(0.017)$ & $(0.030)$ & $(0.021)$ \\
$N$ & 18,196 & 18,196 & 18,196 & 18,196 \\
Firm changers & 0.007 & $0.061^{* * *}$ & $0.095^{* * *}$ & $0.085^{* * *}$ \\
$N$ & $(0.031)$ & $(0.018)$ & $(0.030)$ & $(0.022)$ \\
$N$ & 21,046 & 21,046 & 21,046 & 21,046 \\
\hline
\end{tabular}

Note: The model specification follows the two-step procedure outlined in the text. The Kernel utilized in the first step was an Epanechnikov with a bandwidth of 0.06. Each column reports the conditional difference-in-differences $(\widehat{\delta})$ estimate obtained from the weighted fixed effects estimator on the pooled time sample that lies in the region of common support. This gives the effects of joining a union conditional on observable characteristics between treatment and control groups (namely never union). The errors for these estimates are obtained from a bootstrapping procedure with 100 repetitions. The regressions reported include the demographic and job-specific characteristics outlined in panels (e) and (f) of Section 3.

$* * *, * *$ and $*$ denote statistical significance at the $1 \%, 5 \%$ and $10 \%$, respectively.

respect to the appropriate comparison group. In order to verify that the selection of comparison group is not the driving factor with respect to the findings discussed, the same models have been re-estimated for a group where the control groups are swapped. Thus, joiners in this section will be compared with always union individuals, and mutatis mutandis for union leavers. Unsurprisingly, there is no union wage gain for newcomers with respect to established union members. Remarkably, new union joiners do have an increased probability of holding all of the legally mandated nonwage benefits relative to their 'always union' counterparts. This suggests that perhaps the compensation effects of unionization may be limited to the gains made at the time of the unionization event. This finding holds regardless of the sub-sample analysed.

The losses associated with leaving a union are robust to the selection of control group for leavers as well, and become greater when the comparison group is comprised those individuals who have never unionized. This deterioration for union leavers is apparent for all the sub-samples, and as such is independent of contract type and firm transitions. 
TABLE 5

Conditional Difference-in-Differences Estimates of Leaving a Union, 2005q1-2016q1

\begin{tabular}{lcccc}
\hline LHS & Wages & Bonus & Paid holidays & Pension \\
\hline Baseline & $-0.054^{* *}$ & $-0.041^{* * *}$ & $-0.100^{* * *}$ & $-0.039^{* *}$ \\
& $(0.024)$ & $(0.016)$ & $(0.025)$ & $(0.017)$ \\
$N$ & 6,449 & 6,449 & 6,449 & 6,449 \\
Temporary contract & $-0.376^{* *}$ & -0.039 & 0.077 & -0.096 \\
& $(0.177)$ & $(0.233)$ & $(0.228)$ & $(0.203)$ \\
$N$ & 509 & 509 & 509 & 509 \\
Permanent contract & -0.020 & 0.006 & $-0.070^{*}$ & -0.014 \\
& $(0.031)$ & $(0.010)$ & $(0.037)$ & $(0.020)$ \\
$N$ & 3,976 & 3,976 & 3,976 & 3,976 \\
Exclude micro businesses & $-0.046^{*}$ & $-0.035^{* * *}$ & $-0.104^{* * *}$ & $-0.049^{* * *}$ \\
& $(0.024)$ & $(0.013)$ & $(0.027)$ & $(0.018)$ \\
$N$ & 5,925 & 5,925 & 5,925 & 5,925 \\
Permanent exclude micro & -0.030 & 0.007 & $-0.093^{* * *}$ & $-0.033^{*}$ \\
& $(0.033)$ & $(0.011)$ & $(0.036)$ & $(0.019)$ \\
$N$ & 3,750 & 3,750 & 3,750 & 3,750 \\
Firm stayers & -0.043 & 0.005 & $-0.099^{* *}$ & -0.011 \\
& $(0.036)$ & $(0.020)$ & $(0.048)$ & $(0.022)$ \\
$N$ & 2,605 & 2,605 & 2,605 & 2,605 \\
Firm changers & -0.039 & -0.042 & $-0.082^{*}$ & -0.015 \\
& $(0.033)$ & $(0.032)$ & $(0.045)$ & $(0.029)$ \\
$N$ & 2,326 & 2,326 & 2,326 & 2,326 \\
\hline
\end{tabular}

Note: The model specification follows the two-step procedure outlined in the text. The Kernel utilized in the first step was an Epanechnikov with a bandwidth of 0.06. Each column reports the conditional difference-in-differences $(\widehat{\delta})$ estimate obtained from the weighted fixed effects estimator on the pooled time sample that lies in the region of common support. This gives the effects of joining a union conditional on observable characteristics between treatment and control groups (namely always union). The errors for these estimates are obtained from a bootstrapping procedure with 100 repetitions. The regressions reported include the demographic and job-specific characteristics outlined in panels (e) and (f) of Table 1, with the exception of the firm change variable. The regressions also include state-specific time trends. For definitions of the dependent variables, see text in Section 3.

$* * *, * *$ and $*$ denote statistical significance at the $1 \%, 5 \%$ and $10 \%$, respectively.

Nevertheless, the results from this exercise further demonstrate that the effects of transitioning to/from a union are robust to the choice of the control group.

\section{Classification Error}

There final concern to be addressed is that of classification error. This issue has been raised in the literature, and in particular in the context of measuring the longitudinal effect of unions. The use of longitudinal data, as in this article, has been criticized as issues of measurement error in the union status indicator could create a potential attenuation bias in the $\widehat{\delta}$ estimates obtained. This concern has been treated by Freeman (1984), who under a set of assumptions shows that the longitudinal estimate of the wage gap will bound the 'true' gap, however, this findings rests upon the assumption that there is no selectivity of employers upon the unionization of an establishment. Freeman suggests that for union joiners, it would imply selecting low productivity individuals, while 
in the case of union leavers this would imply more senior workers leaving and seniority rules are likely to invalidate this concern. However, recent evidence by Frandsen (2014) demonstrates such an effect, perhaps invalidating these two assumptions under which the bounding result holds.

Card (1996) provides estimates of the measurement error in longitudinal studies for the USA using CPS data in conjunction with a correlated random effects model with misclassification errors. Utilizing this approach, however, is contingent on knowing something about the rate of misclassification across the distribution of the outcome variable. For Mexico, no such survey exists that would allow one to have a priori knowledge regarding the rate of misclassification. However, the Mexican Statistics Agency when collecting the ENOE survey utilize a digital collection work flow, which for respondents being interviewed a second and subsequent visits contrasts answers given with prior responses, interviewers are then redeployed in the field to ensure that the correct response is coded in survey. The INEGI (2007) report outlines the collection and critique of the survey. Data collection occurs continuously throughout the year by teams of dedicated specialists enumerators, who since 2007 have collected all of the data digitally in a palm pilot tablet. ${ }^{8}$ The data are collected starting on a Monday of a given week, by Wednesday the supervisors will have critiqued the collected data and verified it for internal inconsistencies which may suggest misclassification of indicators. If such a discrepancy is detected enumerators will be sent from Wednesday onwards for re-interviews of households. Thus, while no re-interview survey is subsequently produced as in the the case of the CPS, each response in visits $t+1$ is validated internally, and subsequent visits are validated with respect to the initial response. This suggests that while classification errors are still possible, the methods and practices used by INEGI in the collection of the data seek to minimize these.

Swaffield (2001) considers measurement error in the British Household Panel Survey. She utilizes three approaches to deal with the issue. In the first, measurement error is determined contingent on two questions in the survey in the first the respondent is asked directly about trade union membership, in the second whether they belong to a trade union recognized by management for collective bargaining. In the present study, there are not such analogous questions with which to identify 'true' union members. However, in the context of the FLL such questions would not be able to identify 'true' union members. More than one union may be present in a workplace, but the collective bargaining monopoly is awarded to the first union to organize an establishment. In the second approach, one also adopted by Cai and Waddoups (2011), the 'true' union effect is given by those workers who report joining a union, while simultaneously changing either employer or job. These estimates restrict the number of observations, but also fundamentally change the question being answered. By focusing on those workers who change jobs/employers the union effect is only mediated by the active route to unionization, be it because the worker is seeking to join a union, or has found a better job which happens to be unionized. Nevertheless, estimates 
TABLE 6

Difference-in-Differences Estimates of Joining a Union 2005q1-2016q1, Alternative Control Group

\begin{tabular}{lcccc}
\hline & Wages & Bonus & Paid holidays & Pension \\
\hline Baseline & 0.014 & $0.044^{* * *}$ & $0.119^{* * *}$ & $0.071^{* * *}$ \\
$N$ & $(0.019)$ & $(0.013)$ & $(0.027)$ & $(0.014)$ \\
Temporary contract & 9,666 & 9,666 & 9,666 & 9,666 \\
& -0.087 & 0.038 & -0.066 & 0.087 \\
$N$ & $(0.112)$ & $(0.119)$ & $(0.107)$ & $(0.080)$ \\
Permanent contract & 990 & 990 & 990 & 990 \\
& 0.012 & 0.014 & $0.127^{* * *}$ & $0.034^{* *}$ \\
$N$ & $(0.026)$ & $(0.009)$ & $(0.028)$ & $(0.016)$ \\
Exclude micro businesses & 6,482 & 6,482 & 6,482 & 6,482 \\
& 0.005 & $0.036^{* * *}$ & $0.120^{* * *}$ & $0.058^{* * *}$ \\
$N$ & $(0.021)$ & $(0.012)$ & $(0.029)$ & $(0.014)$ \\
Permanent exclude micro & 8,902 & 8,902 & 8,902 & 8,902 \\
& 0.006 & 0.015 & $0.121^{* * *}$ & $0.032^{* *}$ \\
$N$ & $(0.026)$ & $(0.010)$ & $(0.030)$ & $(0.016)$ \\
Firm stayers & 6,199 & 6,199 & 6,199 & 6,199 \\
$N$ & 0.000 & $0.057^{* * *}$ & $0.182^{* * *}$ & $0.084^{* * *}$ \\
$N$ & $(0.029)$ & $(0.020)$ & $(0.039)$ & $(0.026)$ \\
Firm changers & 3,613 & 3,613 & 3,613 & 3,613 \\
& 0.045 & $0.047^{*}$ & $0.100^{* *}$ & $0.074^{* * *}$ \\
$N$ & $(0.031)$ & $(0.025)$ & $(0.042)$ & $(0.028)$ \\
\hline
\end{tabular}

Note: The control group for joiners in these regressions are always union member individuals. The model specification follows the text. Each column reports the difference-in-differences $(\widehat{\delta})$ estimate obtained from the pooled time sample. This gives the effects of joining a union independent of the business cycle. The errors for these estimates are clustered at the municipal level. The regressions reported include the demographic and job-specific characteristics outlined in panels (e) and (f) of Table 1. The regressions also include state-specific time trends. For definitions of the dependent variables, see text in Section 3.

$* * *, * *$ and $*$ denote statistical significance at the $1 \%, 5 \%$ and $10 \%$, respectively.

for job changers are presented throughout the present analysis in Tables 2, 3,6 and 7. In all of these tables, the main results presented remain invariant, namely that there are gains in legally mandated non-wage benefits for union joiners, and losses for those who leave unions. The final strategy adopted by Swaffield to account for measurement error is to apply averaging on the union indicator. This strategy relies on having access to the union question for more than two periods, and due to the restrictions of ENOE, and in particular the application of the extended questionnaire is not possible using the data structure already outlined.

In summary one would expect that the introduction of measurement error in the union status of an individual would bias the estimates of the $\delta$ parameter downwards towards zero. One can illustrate the effect of a random classification error through the use of a simulation. Assume the known state of joiners is determined at time $t=0$, then a random selection is made to some per cent of the estimation sample. This sub-sample has their union status altered to its opposite value. So, for example, if one decides to induce $n$ per cent measurement error in the union variable, a $n$ per cent random sub-sample is 
TABLE 7

Difference-in-Differences Estimates of Leaving a Union, 2005q1-2016q1, Alternative Control Group

\begin{tabular}{lcccc}
\hline & Wages & Bonus & Paid holidays & Pension \\
\hline Baseline & $-0.026^{*}$ & $-0.057^{* * *}$ & $-0.122^{* * *}$ & $-0.054^{* * *}$ \\
$N$ & $(0.014)$ & $(0.011)$ & $(0.017)$ & $(0.012)$ \\
Temporary contract & 82,650 & 82,650 & 82,650 & 82,650 \\
& $-0.135^{* * *}$ & $-0.189^{* * *}$ & $-0.114^{* *}$ & $-0.146^{* *}$ \\
$N$ & $(0.047)$ & $(0.070)$ & $(0.057)$ & $(0.061)$ \\
Permanent contract & 35,032 & 35,032 & 35,032 & 35,032 \\
& -0.024 & -0.013 & $-0.098^{* * *}$ & -0.007 \\
$N$ & $(0.020)$ & $(0.008)$ & $(0.024)$ & $(0.014)$ \\
Exclude micro businesses & 27,952 & 27,952 & 27,952 & 27,952 \\
& -0.022 & $-0.050^{* * *}$ & $-0.127^{* * *}$ & $-0.051^{* * *}$ \\
$N$ & $(0.018)$ & $(0.011)$ & $(0.019)$ & $(0.013)$ \\
Permanent exclude micro & 43,420 & 43,420 & 43,420 & 43,420 \\
& -0.024 & -0.010 & $-0.106^{* * *}$ & -0.009 \\
$N$ & $(0.022)$ & $(0.009)$ & $(0.026)$ & $(0.014)$ \\
Firm stayers & 22,049 & 22,049 & 22,049 & 22,049 \\
& -0.024 & $-0.048^{* * *}$ & $-0.140^{* * *}$ & $-0.058^{* * *}$ \\
$N$ & $(0.027)$ & $(0.015)$ & $(0.035)$ & $(0.017)$ \\
Firm changers & 24,606 & 24,606 & 24,606 & 24,606 \\
& $-0.041^{*}$ & $-0.068^{* * *}$ & $-0.121^{* * *}$ & $-0.051^{* * *}$ \\
$N$ & $(0.023)$ & $(0.019)$ & $(0.025)$ & $(0.019)$ \\
& 38,241 & 38,241 & 38,241 & 38,241 \\
\hline
\end{tabular}

Note: The control group for leavers in these regressions are never union member individuals. The model specification follows the text. Each column reports the difference-in-differences $(\widehat{\delta})$ estimate obtained from the pooled time sample. This gives the effects of joining a union independent of the business cycle. The errors for these estimates are clustered at the municipal level. The regressions reported include the demographic and job-specific characteristics outlined in panels (e) and (f) of Table 1. The regressions also include state-specific time trends. For definitions of the dependent variables, see text in Section 3.

$* *, * *$ and $*$ denote statistical significance at the $1 \%, 5 \%$ and $10 \%$, respectively.

selected and their union status is recoded. So if one was a joiner they will be miscoded as a never union, and vice versa. This sample is then used to estimate the $\delta$ parameter and the simulation exercise is repeated a number of times. If attenuation bias is a concern, we should observe the parameter being diluted to zero.

The plots shown in Figures 1a and 1b, report the outcomes of such an exercise for all of the main outcomes for the baseline regressions reported in Tables in 2 and $3 .^{9}$ The results illustrate that the reported results are invariant to random measurement errors. The graphs show in a solid black line the resulting parameter estimates given by each simulation with their associated confidence interval shown in grey. These can be compared to the estimate obtained from Tables 2 and 3, which is reproduced for clarity as a maroon dot with its associated confidence interval as a candle stick. As it can be seen, a 5 per cent misclassification in the union status does not change the parameter estimate in a statistically significant manner. A priori, there is no good reason to assume why the error would be non-random, but if this were the case and a suitable data generating process could be approximated, then this approach 
FIGURE 1

Plots of Simulations Inducing 5\% Measurement Error in Treatment Variable [Colour figure can be viewed at wileyonlinelibrary.com]

(a) Joiners
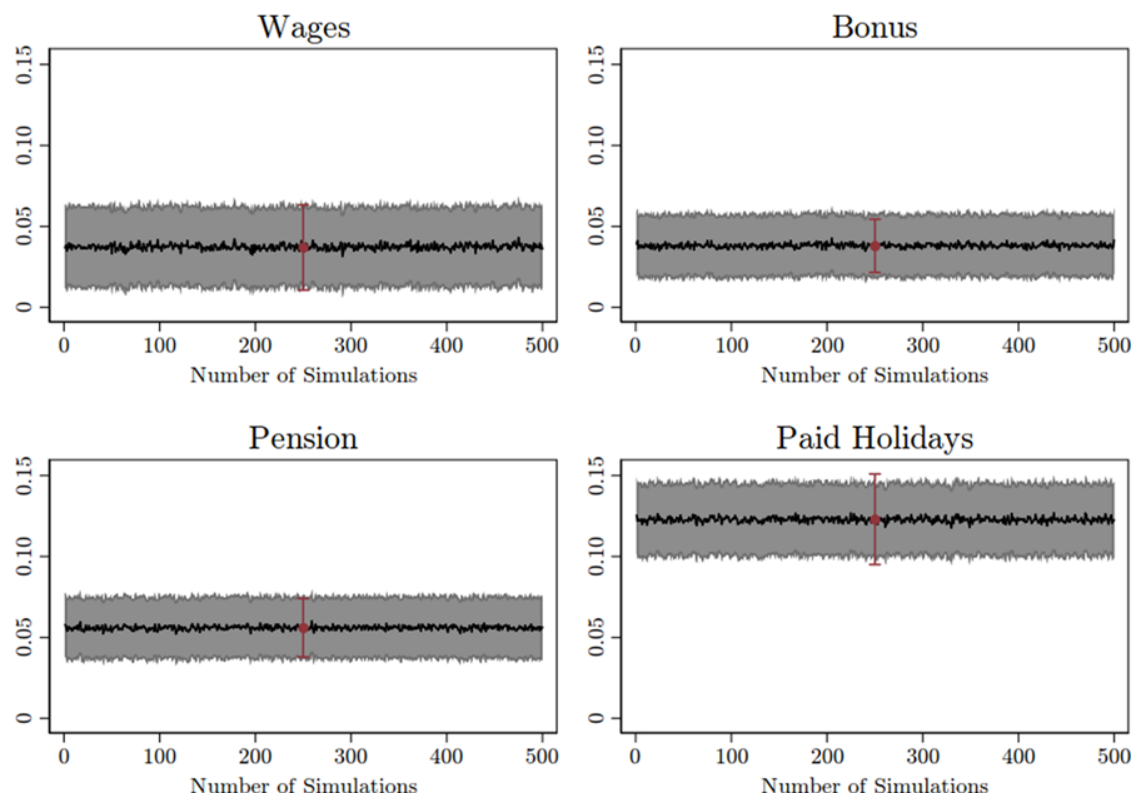

Note: These plots are the results of a simulation inducing a $5 \%$ measurement error on the status of union joiners/transition at time $t=0$. The Measurement error is the symmetric swapping of an individual's status. Thus, if one was a joiner and are selected as part of the $5 \%$ of recodes, they would be falsely attributed as never union, mutatis mutandi for leavers. This exercise was repeated 100 times per outcome and sub-sample and then the same difference-in-differences parameter as given in Tables 2 and 3 was computed 100 times. The black line is the plot of this estimate. The area shaded in grey is the confidence intervals from these. The estimate given by the red dot and red confidence intervals are those obtained from the unaltered data, and are reported in Tables 2 and 3 . The results illustrate that the reported results are invariant to random measurement errors. A priori, there is no good reason to assume why the error would be non-random, but if this were the case and a suitable data generating process could be approximated, then this approach would allow one to bound the size of the 'true' effect.

would allow one to bound the size of the 'true' effect. Nevertheless, the results from this exercise, considered alongside the methodological practice in data collection by INEGI, are compelling evidence that measurement error does not appear to be a big concern in the present analysis.

\section{Conclusions}

The empirical analysis undertaken in this article provides evidence on the pay package gain (loss) associated with joining (leaving) a union in Mexico during a period of deunionization. 
FIGURE 1

Continued.

(b) Leavers
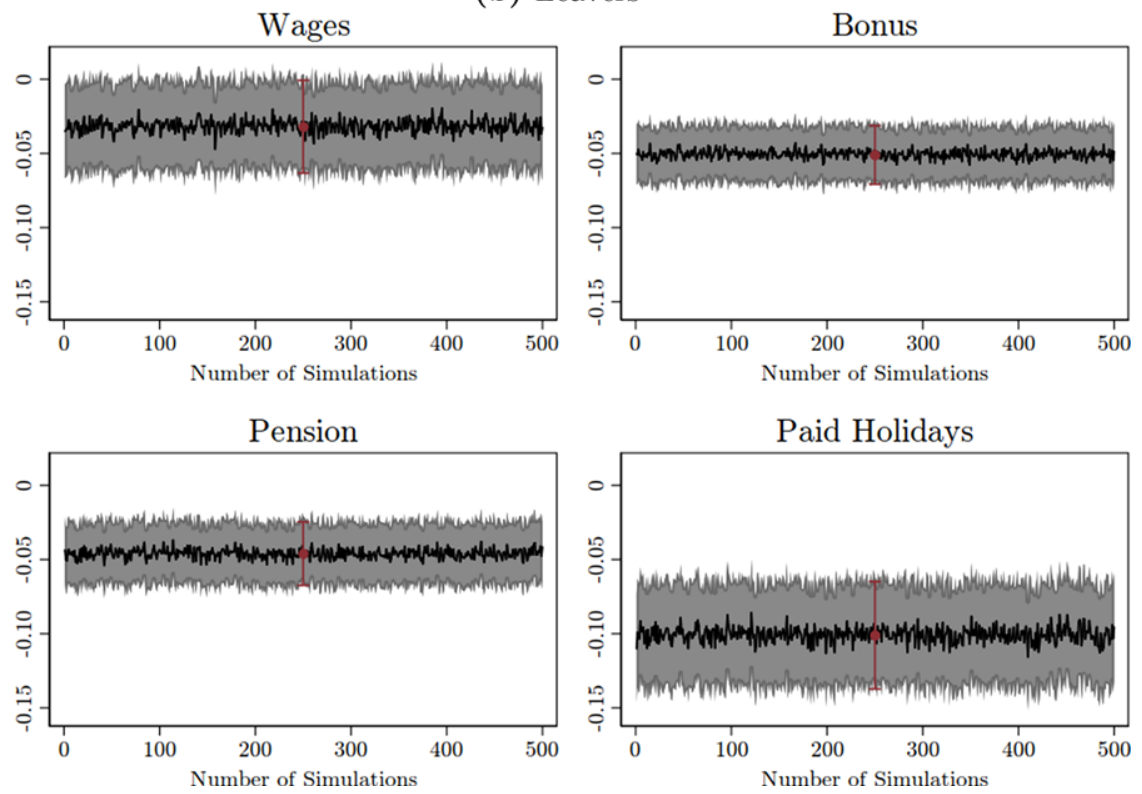

I use a rich labour force survey of the Mexican labour market with a sample size of 46,158 salaried private employees in the formal sector aged between 16 and 64. The real wage (in 2010 Pesos) is calculated for the hourly wages net of any non-wage benefits that individuals receive from their main job. A fixed effects model was applied to see what are the transitional gains in terms of wages or the probability of receipt of non-wage benefits.

The estimates presented provide a consistent story. With respect to wages, joiners are found to be better off than their 'never unionised' counterparts, but this finding is predominantly driven by joiners who hold temporary contracts. For leavers, I find a there is a decline in wages for these same temporary contract workers, and a marginal finding for those who leave a union and stay in their job.

However, workers who exit unions and hold a temporary contract are subject to a wage decrease of 39.1 per cent, but when matched on characteristics this effect reduces to 37.6 per cent. This difference remains despite the approximate 5.7 hour increase in hours worked for the average union leaver. Thus, the estimates suggest a double effect, fewer wages with union leavers are now working more hours to achieve this rate.

The real gains (and losses) associated with union status are the non-wage components of pay packages. Union joiners experience sizeable increases in the probability of being in receipt of mandatory benefits, such as bonuses and paid holidays. The magnitudes for these gains vary but range between 3.8 
and 12.3 percentage points, which when evaluated at pre-transition incidence rates suggest sizeable gains of 3.2-15.2 per cent relative to those individuals who never unionize. Conceptually trying to disentangle between union voice and union facilitation, I suggest that due to the salience of bonuses and paid holidays to workers it is more likely that union voice is driving the increases in non-wage benefit holding, as opposed to increased awareness of existing benefits due to unionization. Consistent with a different profile of the median union member it appears that the workers who stand to benefit most are those for whom benefits are not guaranteed under the FLL. Union leavers are found to have a lower probability of holding non-wage benefits. This trend is detected in a consistently lower probability of holding legally mandated benefits, regardless of whether one has been at the same firm or not. These findings again are contrary to the predictions of the facilitation effect, as union leavers should be those workers who have a heightened awareness of their legal entitlements. Thus, the decline in benefits for those who leave a union and change job at the same time must be interpreted as non-compliance with the law.

The findings presented in this article suggest that despite the decline in union membership over the last decade, unions have adapted their bargaining strategies. Union rhetoric of increasing a worker's 'social wage' has some merit, and may help an individual maintain their living standards. Further, the evidence presented here suggests that unions are still an important institution in the Mexican labour market. In the absence of strong regulation they ensure that workers who decide to unionize see their compensation package reflect their legal entitlement. Individuals who choose to leave unions effectively trade these benefits, perhaps in exchange for retaining their wages at a previously union determined level.

Final version accepted on 1 February 2019

\section{Acknowledgements}

I would like to thank two anonymous referees for their invaluable comments, Andrew Newell, Mirko Moro, Cecilia Poggi, Antonia Schwarz, Jorge Garcia Hombrados, Edgar Salgado Chavez, the participants of the Sussex $2014 \mathrm{PhD}$ conference, XX LACEA Conference in Santa Cruz, and my colleagues at Sussex for their constructive comments. I am grateful for the support of my PhD supervisors Barry Reilly and Paolo Masella for their advice and comments throughout this work. All remaining errors are my own.

\section{Notes}

1. For an exhaustive review of the earlier literature, see Lewis $(1963,1986 a)$.

2. However, even with this approach, there remains an identification problem, where estimates for sub-groups of variables are sensitive to the base group used in estimation. 
3. Namely the CPS, the National Longitudinal Survey of Older Men, the Panel Study of Income Dynamics and the Quality of Employment Survey.

4. These are 2005q1-2006q2, 2007q2, 2008q2, 2009q1, 2010q1, 2011q1, 2012q1, 2013q1, 2014q1, 2015q1 and 2016q1.

5. It is worth noting that in certain contexts the usage of difference-in-differences model to obtain the ATT will yield biased standard errors. Bertrand et al. (2004) identify such a scenario, where there is a limited number of groups for whom the treatment occurs. In their context the assignment group of the treatment is akin to a policy occurring in a given geographic unit and the treatment being attributed to residents in that unit. Their concerns regard difference-in-differences with a small $n$ and a large $t$, the context in this article is different as we have a multitude of individuals for whom each period are observed to be unionized, or not. Nevertheless one commonly identified solution to these concerns is to account for the correlation across treatment units by clustering the data up by one level (Angrist and Pischke 2009). So in this instance all of the estimates presented here have been clustered at the municipal level.

6. This extensive margin can be computed by multiplying the mean proportion prior to transition by the estimated coefficient $\widehat{\delta}$ of joiners. The relevant proportion for this calculation is available in Table 1 , and is 88.6 per cent. So, $0.886 \times 0.037=0.032$.

7. It should be noted that the choice of bandwidth may affect the results of this approach. However, in this particular application alternate bandwidths spanning the range $[0.04,0.12]$ were employed, and the results are not significantly altered. These are available from the author upon request.

8. Prior to this the data were collected on paper and pencil. For some areas where the enumerators deem necessary the data are still collected in paper format. However, this is then digitized and critiqued for internal consistency in responses.

9. The simulations were run in fact for all of the sub-samples, however, these are not reported here, but are available from the author upon request.

\section{References}

Addison, J., Teixeira, P., Evers, K. and Bellman, L. (2013). 'Indicative and Updated Estimates of the Collective Bargaining Premium in Germany'. Discussion Paper 7474, IZA, Bonn.

Angrist, J. and Pischke, J.-S. (2009). Mostly Harmless Econometrics: An Empiricist's Companion. Princeton, NJ: Princeton University Press.

Arbache, J. S. and Carneiro, F. G. (1999). 'Unions and interindustry wage differentials'. World Development, 27 (10): 1875-83.

Baah, A. Y. (2005). 'An Empirical Analysis of the Labour Market and Trade Union Effects in Ghana'. PhD Thesis, University of Sussex, Brighton.

Bensusán, G. and Middlebrook, K. J. (2012). El Sindicalismo y la democratización en México. Foro Internacional, 52 (4): 796-835.

Bertrand, M., Duflo, E. and Mullainathan, S. (2004). 'How much should we trust differences-in-differences estimates?'. Quarterly Journal of Economics, 119 (1): 24975.

Bhandari, A. K. (2009). 'Does union membership pay off? Evidence from organized manufacturing industries in India'. Indian Journal of Industrial Relations, 43 (3): 43 74. 
Blinder, A. (1973). 'Wage discrimination: reduced form and structural estimates'. Journal of Human Resources, 8 (3): 436-55.

Blunch, N.-H. and Verner, D. (2004). 'Asymmetries in the union wage premium in Ghana'. World Bank Economic Review, 18 (2): 237-52.

Booth, A. L. and Bryan, M. L. (2004). 'The union membership wage-premium puzzle: is there a free rider problem?'. Industrial and Labor Relations Review, 57 (3): 402-21.

Budd, J. W. (2004). 'Non-wage forms of compensation'. Journal of Labor Research, 25 (4): 597-622.

(2005). 'The effect of unions on employee benefits: updated employer expenditure results'. Journal of Labor Research, 26 (4): 669-76.

(2007). 'The effect of unions on employee benefits and non-wage compensation: monopoly power, collective voice, and facilitation'. In J. T. Bennett and B. E. Kaufman (eds.), What Do Unions Do? A Twenty Year Perspective. London: Taylor \& Francis, pp. 160-92.

and Brey, A. (2003). 'Unions and family leave: early experience under the Family and Medical Leave Act'. Labor Studies Journal, 28 (1): 85-105.

_ and McCall, B. P. (1997). 'The effect of unions on the receipt of unemployment insurance benefits'. Industrial and Labor Relations Review, 50 (3): 478-92.

— and Mumford, K. (2004). 'Trade unions and family-friendly policies in Britain'. Industrial and Labor Relations Review, 57 (2): 204-22.

Butcher, K. F. and Rouse, C. E. (2001). 'Wage effects of unions and industrial councils in South Africa'. Industrial and Labor Relations Review, 54 (2): 349-74.

Cai, L. and Waddoups, C. J. (2011). 'Union wage effects in Australia: evidence from panel data'. British Journal of Industrial Relations, 49 (s2): s279-s305.

Callan, T. and Reilly, B. (1993). 'Unions and the wage distribution in Ireland'. Economic and Social Review, 24 (4): 297-312.

Card, D. (1996). 'The effect of unions on the structure of wages: a longitudinal analysis'. Econometrica, 64 (4): 975-79.

, Lemieux, T. and Riddell, W. C. (2018). 'Unions and Wage Inequality: The Roles of Gender, Skill and Public Sector Employment'. NBER Working Papers, National Bureau of Economic Research.

Casoni, A., Labadie, G. J. and Fachola, G. (2005). 'The economic effects of unions in Latin America: their impact on wages and the economic performance of firms in Uruguay'. In P. Kuhn and G. Márquez (eds.), What Difference Do Unions Make? Their Impact on Productivity and Wages in Latin America. Washington, DC: InterAmerican Development Bank, pp. 101-42.

DiNardo, J. and Lee, D. S. (2004). 'Economic impacts of new unionization on private sector employers: 1984-2001.' Quarterly Journal of Economics, 119 (4): 1383-441.

Doucouliagos, H., Freeman, R. B., Laroche, P. and Stanley, T. (2018). 'How credible is trade union research? Forty years of evidence on the monopoly-voice trade-off'. Industrial and Labor Relations Review, 71 (2): 287-305.

Ehrenberg, R. G. and Schwarz, J. L. (1986). 'Public-sector labor markets'. In O. Ashenfelter and R. Layard (eds.), Handbook of Labor Economics, Vol. II. North Holland: Elsevier, pp. 1219-68.

Fairris, D. (2003). 'Unions and wage inequality in Mexico'. Industrial and Labour Relations Review, 56 (3): 481-97.

(2006). 'Union voice effects in Mexico'. British Journal of Industrial Relations, 44 (4): 781-800.

(2007). 'Que hacen los sindicatos en México?' Estudios Económicos, 22 (2): 185240. 
Fields, G. S. and Yoo, G. (2000). 'Falling labor income inequality in Korea's economic growth: patterns and underlying causes'. Review of Income and Wealth, 46 (2): 13959.

Firpo, S., Fortin, N. M. and Lemieux, T. (2009). 'Unconditional quantile regressions'. Econometrica, 77 (3): 953-73.

Frandsen, B. R. (2014). 'The surprising impacts of unionization: evidence from matched employer-employee data'. Economics Department, Brigham Young University, mimeo.

Freeman, R. B. (1981). 'The effect of unionism on fringe benefits'. Industrial and Labor Relations Review, 34 (4): 489-509.

- (1984). 'Longitudinal analyses of the effects of trade unions'. Journal of Labor Economics, 2 (1): 1-26.

(2010). 'Labor regulations, unions, and social protection in developing countries: market distortions or efficient institutions?' In D. Rodrik and M. Resenzweig (eds.), Handbook of Development Economics, Vol. V. North Holland: Elsevier, pp. 4657702.

— and Medoff, J. L. (1984). What Do Unions Do? New York: Basic Books.

Fuchs, V. R., Krueger, A. B. and Poterba, J. M. (1998). 'Economists' views about parameters, values, and policies: survey results in labor and public economics'. Journal of Economic Literature, 36 (3): 1387-425.

Gasparini, L. and Tornaroli, L. (2009). Labor informality in Latin America and the Caribbean: patterns and trends from household survey microdata'. Revista Desarrollo Y Sociedad, 63 (1): 13-80.

Gutierrez Rufrancos, H. (2017). 'What Do Mexican Unions Do?'. PhD Thesis, University of Sussex, Brighton.

Harcourt, M., Wood, G. and Harcourt, S. (2004). 'Do unions affect employer compliance with the law? New Zealand evidence for age discrimination'. British Journal of Industrial Relations, 42 (3): 527-41.

Heckman, J. (1979). 'Sample selection bias as a specification error'. Econometrica, 47 (1): 153-61.

Hirsch, B. T., Macpherson, D. A. and DuMond, J. M. (1997). 'Workers' compensation recipiency in union and nonunion workplaces'. Industrial and Labor Relations Review, 50 (2): 213-36.

Hirschman, A. O. (1971). Exit, Voice, and Loyalty. Cambridge, MA: Harvard University Press.

Hofmeyr, J. F. and Lucas, R. E. B. (2001). 'The rise in union wage premiums in South Africa'. Labour, 15 (4): 685-719.

ILO (1991). 'The Dilemma of the Informal Sector'. Report of the Director-General (Part I) to the 78th Session of the International Labour Conference. Technical Report, International Labour Organisation, Geneva.

— (2002). 'Decent Work and the Informal Economy'. ILO IV Report to the 90th Session of the International Labour Conference. Technical Report, International Labour Organisation, Geneva.

INEGI (2007). Como se hace la enoe. metodos y procedimientos. Technical Report, Instituto Nacional de Estadística y Geografía, Mexico City.

Jarrell, S. B. and Stanley, T. D. (1990). 'A meta-analysis of the union-nonunion wage gap'. Industrial and Labor Relations Review, 44 (1): 54-67.

Kleiner, M. M. and Lee, Y. (1997). 'Works councils and unionization: lessons from South Korea'. Industrial Relations: A Journal of Economy and Society, 36 (1): 1-16. 
Kornfeld, R. (1993). 'The effects of union membership on wages and employee benefits'. Industrial and Labor Relations Review, 47 (1): 114-28.

Landerretche, O., Lillo, N. and Puentes, E. (2011). 'The Union Effect on Wages in Chile: A Two-Stage Approach Using Panel Data'. Working paper SDT 332, Departamente De Economía, Universidad de Chile, Santiago.

and - (2013). 'The union effect on wages in Chile: a two-stage approach using panel data'. Labour, 27 (2): 164-91.

Lee, L.-F. (1978). 'Unionism and wage rates: a simultaneous equations model with qualitative and limited dependent variables'. International Economic Review, 19 (2): 415-33.

(1983). 'Generalised econometric models with selectivity'. Econometrica, 51 (2): 507-12.

Lewis, H. G. (1963). Unionism and Relative Wages in the United States: An Empirical Inquiry. Chicago, IL: University of Chicago Press.

— (1986a). 'Union relative wage effects'. In O. Ashenfelter and R. Layard (eds.), Handbook of Labor Economics, Vol. II. North Holland: Elsevier, pp. 1139-81.

— (1986b). Union Relative Wage Effects: A Survey. Chicago, IL: University of Chicago Press.

Loayza, N. and Sugawara, N. (2009). 'El sector informal en Mexico: Hechos y explicaciones fundamentales'. El Trimestre Economico, 74 (4): 887-920.

Main, B. and Reilly, B. (1992). 'Women and the union wage gap'. Economic Journal, 102 (410): 49-66.

Menezes-Filho, N., Zylberstajn, H., Chahad, J. P. and Pazello, E. (2005). 'Unions and the economic performance of Brazilian establishments'. In P. Kuhn and G. Márquez (eds.), What Difference Do Unions Make? Their Impact on Productivity and Wages in Latin America. Washington, DC: Inter-American Development Bank, pp. 77-100.

Middlebrook, K. J. (1995). The Paradox of Revolution: Labor, the State, and Authoritarianism in Mexico. Baltimore, MD: Johns Hopkins University Press.

Miller, P. and Mulvey, C. (1992). 'Trade unions, collective voice and fringe benefits'. Economic Record, 68 (201): 125-41.

Moll, P. G. (1993). 'Black South African unions: relative wage effects in international perspective'. Industrial and Labor Relations Review, 46 (2): 245-61.

Montgomery, E. and Shaw, K. (1997). 'Pensions and wage premia'. Economic Enquiry, 35 (3): $510-22$.

Oaxaca, R. (1973). 'Male-female wage differentials in urban labor markets'. International Economic Review, 14 (3): 693-709.

Panagides, A. and Patrinos, H. A. (1994). 'Union-Nonunion Wage Differentials in the Developing World: A Case Study of Mexico'. Policy Research Working Paper 1264, World Bank, Washington, DC.

Park, K. S. (2008). 'Non-standard employment'. In R. B. Freeman, S. Kim, and J. Keum (eds.), Beyond Flexibility Roadmaps for Korean Labor Policy. Seoul: Korea Labor Institute, pp. 261-77.

Pencavel, J. H. (1974). 'Relative wages and trade unions in the United Kingdom'. Econometrica, 41 (164): 194-210.

Pradhan, M. and van Soest, A. (1995). 'Formal and informal sector unemployment in urban areas in Bolivia'. Labour Economics, 2 (3): 275-97.

Rios-Avila, F. and Hirsch, B. T. (2012). 'Unions, wage gaps, and wage dispersion: new evidence from the Americas'. Discussion Paper 6757, IZA, Bonn.

— and - (2014). 'Unions, wage gaps, and wage dispersion: new evidence from the Americas'. Industrial Relations: A Journal of Economy and Society, 53 (1): 1-27. 
Robinson, C. (1989). 'Union endogeneity and self-selection'. Journal of Labor Economics, 7 (1): 106-12.

and Tomes, N. (1984). 'Union wage differentials in the public and private sector: a simultaneous equations specification'. Journal of Labor Economics, 2 (1): 106-27.

Rubin, D. B. (1974). 'Estimating causal effects of treatments in randomized and nonrandomized studies'. Journal of Educational Psychology, 66 (5): 688-701.

Schultz, P. T. and Mwabu, G. (1998). 'Labor unions and the distribution of wages and employment in South Africa'. Industrial and Labor Relations Review, 51 (4): 680703.

Slichter, S. H., Healy, J. J. and Livernash, R. E. (1960). The Impact of Collective Bargaining on Management. Washington, DC: The Brookings Institution.

Smith, J. A. and Todd, P. E. (2005). 'Does matching overcome LaLonde's critique of nonexperimental estimators'. Journal of Econometrics, 125: 305-53.

Standing, G. (1992). 'Do unions impede or accelerate structural adjustment? Industrial versus company unions in an industrialising labour market'. Cambridge Journal of Economics, 16 (3): 327-54.

Stewart, M. B. (1983). 'Relative earnings and individual union membership in the United Kingdom'. Economica, 50 (198): 111-25.

Swaffield, J. K. (2001). 'Does measurement error bias fixed-effects estimates of the union wage effect?'. Oxford Bulletin of Economics and Statistics, 63 (4): 437-57.

Swindinsky, R. and Kupferschmidt, M. (1991). 'Longitudinal estimates of the union effects on wages, wage dispersion and pension fringe benefits'. Relations Industrielles, 46 (4): 819-38.

\section{Appendix A: Conditional Difference-in-Differences}

The differences-in-differences estimate $\widehat{\delta}$ is the ATT. This may be re-cast within the Rubin (1974) framework of potential outcomes as follows

$$
\begin{aligned}
\mathrm{ATT} & \equiv E\left(y_{1 i q}-y_{0 i q} \mid U_{i}=1\right) \\
& =E\left\{E\left(y_{1 i q}-y_{0 i q} \mid U_{i}=1, X_{i}\right) \mid U_{i}=1\right\}(\text { by iterated expectations }) \\
& =E\left\{E\left(y_{1 i q} \mid U_{i}=1, X_{i}\right)-E\left(y_{0 i q} \mid U_{i}=1, X_{i}\right) \mid U_{i}=1\right\} \\
& =E\left\{E\left(y_{1 i q} \mid U_{i}=1, X_{i}\right)-E\left(y_{0 i q} \mid U_{i}=0, X_{i}\right) \mid U_{i}=1\right\}
\end{aligned}
$$

This may be simplified as:

$$
=E\left(\delta_{X} \mid U_{i}=1\right)
$$

The propensity score version of the ATT may be expressed as follows:

$$
\begin{aligned}
\mathrm{ATT}^{p s m} & \equiv E\left(y_{1 i q}-y_{0 i q} \mid U_{i}=1\right) \\
& =E\left\{E\left(y_{1 i q}-y_{0 i q} \mid U_{i}=1, p\left(X_{i}\right)\right) \mid U_{i}=1\right\}(\text { by iterated expectations) } \\
& =E\left\{E\left(y_{1 i q} \mid U_{i}=1, p\left(X_{i}\right)\right)-E\left(y_{0 i q} \mid U_{i}=1, p\left(X_{i}\right)\right) \mid U_{i}=1\right\} \\
& =E\left\{E\left(y_{1 i q} \mid U_{i}=1, p\left(X_{i}\right)\right)-E\left(y_{0 i q} \mid U_{i}=0, p\left(X_{i}\right)\right) \mid U_{i}=1\right\} \quad \text { (A2) }
\end{aligned}
$$


Thus, the expression in (A1). The difference lies in the use of a control function $p\left(X_{i}\right)$ which allows one to compute the propensity score. Thus, one estimates a probit containing the $X_{i}$ vector of characteristics. From this procedure, one takes the sample of individuals that lie in the common support region, $0<\hat{p}\left(X_{i}\right)<1$, discarding all individuals for whom $\hat{p}\left(X_{i}\right)=1$. However, it is unlikely that one may find exact matches. Thus, one must use the distance between matched treated and control units as a weighting factor.

Smith and Todd (2005) show that the typical matching estimator can be expressed as:

$$
\begin{aligned}
\hat{\delta}_{A T T}^{p s m} & =\frac{1}{n_{1}} \sum_{i \in I_{1} \cap S_{p}}=\left[y_{1 i q}-\hat{E}\left(y_{0 i} \mid U_{i}=1, p\left(X_{i}\right)\right)\right] \\
& =\frac{1}{n_{1}} \sum_{i \in I_{1} \cap S_{p}}=\left[y_{1 i q}-\sum_{j \in I_{0}} W(i, j) y_{0 j}, I_{1}\right]
\end{aligned}
$$

where $I_{1}$ is the set of status changers, and their control group is denoted by $I_{0}$. The region of common support is $S_{p}$, and $n_{1}$ the number of individuals in the set $I_{1} \cap S_{p}$. Finally, $W(i, j)$ is the weights derived from the distance of matched observation $i$ and $j$ given by the estimated $\hat{p}\left(X_{i}\right)$ and $\hat{p}\left(X_{j}\right)$, respectively. 